\title{
Integrating remote sensing, GIS and in-situ data for structural mapping over a part of the NW Rif belt, Morocco
}

Omar Skakni , Rachid Hlila , Amin Beiranvand Pour, Manuel Martín Martín , Ali Maate, Soufian Maate, Aidy M Muslim \& Mohammad Shawkat Hossain

To cite this article: Omar Skakni , Rachid Hlila , Amin Beiranvand Pour, Manuel Martín Martín , Ali Maate , Soufian Maate , Aidy M Muslim \& Mohammad Shawkat Hossain (2020): Integrating remote sensing, GIS and in-situ data for structural mapping over a part of the NW Rif belt, Morocco, Geocarto International, DOI: 10.1080/10106049.2020.1852611

To link to this article: https://doi.org/10.1080/10106049.2020.1852611

Accepted author version posted online: 19 Nov 2020.

Submit your article to this journal $₫$

凹 Article views: 34

Q View related articles ¿

View Crossmark data 


\title{
Integrating remote sensing, GIS and in-situ data for structural mapping over a part of the NW Rif belt, Morocco
}

\author{
Omar Skakni ${ }^{1}$, Rachid Hlila ${ }^{1}$, Amin Beiranvand Pour ${ }^{2}$, Manuel Martín Martín ${ }^{3}$, Ali Maate ${ }^{1}$, \\ Soufian Maate ${ }^{1}$, Aidy M Muslim ${ }^{* 2}$ and Mohammad Shawkat Hossain ${ }^{2}$ \\ ${ }^{1}$ Laboratoire de Géologie de l'Environnement, Département de Géologie, Faculté des \\ Sciences, Université Abdelmalek Essaâdi, BP. 2121, Tetouan, Morocco. \\ ${ }^{2}$ Institute of Oceanography and Environment (INOS), Universiti Malaysia Terengganu \\ (UMT), 21030 Kuala Nerus, Terengganu, Malaysia
}

${ }^{3}$ Departamento de Ciencias de la Tierra y Medio Ambiente, Fac. Ciencias, Universidad de Alicante, Spain

${ }^{*}$ Corresponding Author. Tel: +609 -6683824; Fax: +609- 6692166; Email address:

aidy@umt.edu.my;

\begin{abstract}
This study adopts an integrated approach using the geographic information system (GIS) and remote sensing techniques for structural mapping in inaccessible zone of the internal segment of North-Western Rif belt, Morocco. The Principal Component Analysis (PCA), Optimal Index Factor (OIF), band ratios and directional filtering are applied to Landsat 8 OLI (Operational Land Imager) image for mapping lithology and geological structures. Tectonic lineaments are extracted using the remote sensing and GIS approach and verified by in-situ data. Lithology and detailed structural features in the study area as well as the main sets of fractures trending NW-SE and E-W are identified and highlighted. The results obtained in this research demonstrate that the integration of remote sensing imagery and GIS techniques is a reliable and low-cost approach to fracture extraction and structural mapping, particularly in remote and inaccessible regions of the African plate and other analogue zones around the world.
\end{abstract}

Keywords: Remote sensing, GIS, Structural mapping, Calcareous Dorsal Complex, Morocco

\section{Introduction}

Geological features such as tectonic lineaments are important parameters of any structural geological studies. Remote sensing data such as RADARDAT-1, Landsat data series, PALSAR, ASTER, Sentinel-1 and SPOT-5 have been extensively and successfully used to map tectonic structural features around the world in the last decades (Masoud and Koike 2006; Jensen 2015; Pour et al. 2016,2018; Radaideh et al. 2016; Adiri et al. 2017; Ahmadirouhani et al. 2017; Eldosouky et al. 2017; Masoud and Koike 2017; Hamimi et al. 2018; Takodjou Wambo et al. 2018; Azar et al. 2019; Hamdani and Baali 2019; Hosseini et al. 2019; Javhar et al. 2019). Lineament mapping helps track fault structures related to ore mineralizations, oil and gas seepage zones, hydrology and geological hazards (Corgne et al. 2010; Hashim et al. 2013; Pour and Hashim 2017; Alizadeh et al. 2018; Ouko et al. 2018; Hamdani and Baali, 2020).

Lineaments in satellite remote sensing images have topographic relief and/or tonal features which are attributable to the underground 3D structures in the Earth. Lineaments are associated with brittle and ductile deformation zones which shows in remotely sensed images as rectilinear and curvilinear patterns. Spatial analysis of lineament sets helps to reconstruct the tectonic history of a region, and 
also reveals generalities that can help to test process hypotheses (van der Pluijm and Marshak, 1997). Geological lineament features are attributed to paleo-tectonic and/or neo-tectonic of a region.

The use of remote sensing data in delineating of tectonically significant lineaments has been demonstrated in several geological settings (Raharimahefa and Kusky, 2009; Amri et al. 2011; Abdelkareem and El-Baz 2015; Pour et al. 2016, 2018a,b; Kamel and Abdelkareem, 2018; Sekandari et al. 2020; Moradpour et al. 2020; Abdelkareem et al. 2020).

The Rifian Internal Domain (Figure 1a), located in the north of Morocco, has complex geological structures. Few structural geological studies using satellite remote sensing data have been conducted in some parts of this domain. Biju-Duval et al. (1976) used Landsat satellite images for structural mapping in the Rifian Internal area. The Jebha strike-slip fault system was mapped in the Calcareous Dorsal Complex. Moreover, the NE-SW dextral Fahies fault system (Kornprobst 1974) bounding the Internal Domain to the north was identified in this study. Ait Brahim and Sossey Alaoui (2002) used Landsat ETM+ and SPOT XS and ERS-1 SAR radar data to map fault systems in the external portion of the Rif belt (an arcuate mountain belt around the western Mediterranean Sea) (Chalouan and Michard 2004). El Adraoui et al. (2007) used remote sensing technology to highlight the importance of strike-slip faults in the structuration of the Rifian Calcareous Dorsal Complex. A detailed large-scale structural map of the Rifian Internal Domain, however, is not generated, yet. The structural analysis of the Calcareous Dorsal Complex may provide valuable details relating to Alpine orogenic construction and the displacement of transferred faults (WSW to SW) in the Late Oligocene-Miocene (Andrieux 1971; Olivier 1982).

Using the traditional and field campaign methods for mapping lineaments in the Rifian Calcareous Dorsal Complex reveals two main challenges, including (i) the large geographical zone of the Calcareous Dorsal Complex and (ii) the low accessibility of the zone as the carbonate formations exposed in high relief and inaccessible in many parts. In such conditions, the integration of satellite remote sensing imagery and GIS techniques provides a practical approach for better observation, extraction and analysis of geological lineament features. This approach has been used to map lineament and to identify geological structures (e.g. Solomon and Ghebreab 2006; Saadi et al. 2011; Hashim et al. 2013), particularly in the inaccessible and remote areas of tropical regions, Polar regions and Mediterranean areas surrounding the Mediterranean Sea (Alboran Sea) (Figure 1) (Pour et al. 2016, 2018a,b; Hamdani and Baali 2019, 2020). Structural mapping will help to understand and clarify Alpine orogenic construction in the Mediterranean region, as well as identify feasible metallic ore mineralizations, oil, gas and groundwater exploration of and natural hazard mitigation in the Calcareous Dorsal Complex, NW Rif belt, Morocco.

In this study, Landsat 8 OLI(Operational Land Imager), Shuttle Radar Topography Mission (SRTM), and ALOS PALSAR data are used and integrated to map geological structures, i.e., faults and fractures in the Calcareous Dorsal Complex, covering a large region between Talembote and Tetouan cities in northern Morocco (Figure 1). Major objectives of this study are (1) to prepare an enhanced images base as a tool for mapping structural lineaments and lithology of the Calcareous Dorsal Complex using remote sensing image processing techniques; (2) to generate structural lineament and lineament density maps for the study area by integrating the remote sensing products and the existing geological maps using GIS techniques; and (3) to verify the obtained results by comprehensive fieldwork and compare with previous structural studies in the Calcareous Dorsal Complex.

\section{Geological setting and structures of the study area}

The Rifian Internal Domain (Figure 1a) forms with its Betic equivalent the sub-plate of Alboran (Andrieux et al. 1971; Andrieux and Mattauer 1973), or Alboran exotic terrane (Chalouan et al. 2001, 2008; Michard et al. 2002; Chalouan and Michard 2004), a part of the "ALKAPECA" 
domain (Bouillin et al. 1986) also known as a Meso-Mediterranean Terrane (Durand-Delga 1980; Guerrera et al. 1993; Martín Martín et al. 2019; Guerrera et al. 2020). In the Rif, the Internal Domain corresponds to the Sebtide, Ghomaride and Calcareous Dorsal complex units (e.g. DurandDelga 1972; Chalouan et al. 2008) (Figure 1b). The Sebtide complex is formed by several units with successions ranging from Paleozoic to Triassic in age with variable degrees of metamorphism (e.g. Milliard 1959; Durand-Delga and Kornprobst 1963; Kornprobst 1974; Saddiqi et al. 1995; Michard et al. 2006). The Ghomaride complex containing Paleozoic metasediments shows only low metamorphic grade, covered with unconformable sedimentary rocks ranging from Triassic to lower Miocene (e.g. Durand-Delga and Kornprobst 1963; Michard and Chalouan 1991; Chalouan et al. 2008). The Calcareous Dorsal Complex (Fallot 1937), corresponds to a tectonic stack of units formed by: (i) thick Triassic-Liasic carbonates, (ii) upper Lias-Paleocene condensed series, and (iii) upper Oligocene to Aquitanian synorogenic detrital sediments (e.g. Fallot 1937; Griffon 1966; Wildi et al. 1977; Nold et al. 1981; El Kadiri et al. 1992).

The Rif belt corresponds to a thrust sheet system, with a tectonic transport from SW to WSW. The current arcuate geometry is acquired during the Lower-Middle Miocene (e.g. Leblanc and Olivier 1984; Durand-Delga and Olivier 1988; Hlila and Sanz de Galdeano 1994, 1995; Vitale et al. 2014a) and the importance of strike-slip faults is well indicated by several authors when evoking the tectonic evolution of the chain. Hlila and Sanz de Galdeano (1995) also highlighted the importance of transverse faults in the Rifian Calcareous Dorsal tectonic evolution. The Jebha-Chrafate fault is an E-W to ENE-WSW sinistral fault that stretches over $50 \mathrm{~km}$, forming the Internal Rif's southern limit. It was considered as a transfer fault during the WSW-SW displacement of the Rifian Internal Domain (Andrieux et al. 1971; Olivier 1982; Leblanc and Olivier 1984; Benmakhlouf et al. 2005). Hlila et al (2014a, b) recognized a NE-SW system faults in the Oued Laou valley affecting the entire Rifian Internal Zones which controls the opening an intramountain basin in the Pliocene (e.g. Tirinesse basin).

\section{Materials and methods}

\subsection{Remote sensing data used}

We used several data in this analysis, including Landsat 8 (OLI), two geological maps covering the study area (the 1:50000 Tetouan-Ras Mazari and Souk Larbaa Beni Hessane geological maps). The Landsat 8 (OLI) image was downloaded from the USGS Earth Explorer(http://earthexplorer.usgs.gov), which was acquired on July 31, 2018. These data are provided with the Universal Transverse Mercator (UTM) projection and a WGS 84 World Geodetic System. Table 1 shows image characteristics of Landsat8 (OLI) (Irons et al. 2012). The ALOS PALSAR with $12.5 \mathrm{~m}$ DEM and SRTM data were obtained from the Alaska Satellite Facility's data portal (https://vertex.daac.asf.alaska.edu/). PALSAR DEM and SRTM data (Nikolakopoulos et al. 2006; Igarashi 2001) are used mainly to validate the geological structures extracted from Landsat 8 (OLI) data.

\subsection{Image Processing techniques}

Several techniques have been adopted to identify the geological linear features in the study area, namely Optimum Index Factor, Principal Component Analysis, Band Ratios, and Directional

Filtering. Figure 2 shows the methodological flowchart used in this study.

\subsubsection{Principal Component Analysis}


Image transformation technique, along with Principal Component Analysis (PCA) is often used in the tectonic lineament extraction (Majumdar and Bhattacharya 2007; Adiri et al. 2017; Mhamdi et al. 2017; Pandey and Sharma 2019). It consists of condensing the information contained in several bands, sometimes highly correlated and containing similar information, into a few variables, called principal components (PCs). The PCA is capable of determining the direction of space that contains the highest sample variance and moving on to the orthogonal subspace in this direction to find the next highest variance. The result is iteratively discovering an ordered orthogonal basis of the highest variance. The first three PCs represent an excellent product of the data variability with a maximum proportion of variance of information (Richards 1999). The first three PCs allows the condensation of high-quality information representing $98.96 \%$ of the total data variance (Table 2). The subspace defined by the first $n$ PCA vectors explain a given percentage of the variance. The subspace of dimension $n$ explains the largest possible fraction of the total variance (Richards 1999). The PC1 contains the albedo which is related largely to the topographic features. The first three PC images (PC1, PC2 and PC3), containing the highest topographical and spectral information, are suitable for lithological discrimination. The composite of PC1, PC2, and PC3 as RGB image allows differentiating the lithological units and geological structures in the study area. Thus, the PC1 is used to extract lineaments in the study area.

\subsubsection{Optimum index factor analysis}

Chavez et al. (1982) developed an optimum index factor (OIF) method to calculate the optimum combination of every possible three bands in a satellite image, which contains the maximum of information. ILWIS 3.31 Academic (https://www.itc.nl/ilwis/download/ilwis33/), was used in the current study using the following algorithm to calculate the highest-ranked OIF index:

$$
\mathrm{OIF}=\left[\frac{\sum_{k=1}^{n} s_{k}}{\sum_{j=1}^{n}\left|r_{j}\right|}\right](1)
$$

where, sk is the standard deviation of $\mathrm{k}$ band, and $\mathrm{r}(\mathrm{j})$ represents the correlation matrix value of each two OLI bands (Tables 3 and 4). The combination of the three bands with the largest OIF generally has the most information (measured by variance) with the least amount of duplication (measured by correlation) (Jensen 2015). Table 5 shows the OIF of all possible combinations of three bands. It shows the composite of bands 5, 4 and 1 is the best combination for mapping lithological/alteration since these bands provide more details and score than other bands.

\subsubsection{Band ratios analysis}

The band ratioing method consists of dividing the pixels of one spectral band by a corresponding one in the image of the other band (Borra et al. 2019) which reduces the topographic effect (Amri et al. 2011; Jensen 2015). The generated band-ratio image is useful in distinguishing between the surface materials characteristics (Jensen 2015). In this study, we combine the band ratio analysis with the PCA, a technique that has been widely used in various scientific fields (Rahman et al. 2013; Aldjazouli et al. 2019). For band ratioing analysis in this study, the PC containing the most negative or positive contribution/loading are selected for mapping lithology and alteration zones (see Table 2).

\subsubsection{Enhancement and extraction of lineaments}

Spatial transforms provide reliable and robust image processing techniques to extract the spatial information from remote sensing data. The technique helps to maximize clarity, sharpness and details of features of interest and further analysis. Spatial convolution filtering is primarily based on 
the use of convolution masks. Linear features are formed by edges in remotely sensed images. Some linear features occur as narrow lines against a background of contrasting brightness; others are the linear contact between adjacent areas of different brightness. Edge enhancement delineates these edges and renders the image shapes and features more visible and easier to analyze (Jensen, 2015). Directional filters improve the perception of lineaments by creating an optical effect on the image (Marion 1987; Jensen 2015). This technique is very beneficial for detecting the oriented linear geological structures (Robert 1997; Majumdar and Bhattacharya 1988). Accordingly, directional filters were used in produced PC1 image to enhance particular linear trends. Four principal directional filters, including N-S, E-W, NE-SW, and NW-SE with a $7 * 7$ kernel size were applied (Table 6). 7*7 kernel matrix was applied in this analysis for enhancing semi-smooth and smooth/rough features (Jensen 2015). Directional filter angles were adjusted as N-S: $0^{\circ}, \mathrm{E}-\mathrm{W}: 90^{\circ}$, NE-SW: $45^{\circ}$, and NW-SE: $135^{\circ}$. The directional filters of N0, N45, N90 and N135 were applied to the PC1 for extracting lineaments.

PC1 image derived from PCA analysis was processed using Automatic Lineament Extraction algorithm (PCI-LINE) for calculating fault density and lineament extraction. The PCI-LINE module typically extracts lineaments in three steps, namely (i) edge detection, (ii) thresholding and (iii) curve extraction. Lineament was extracted in the ArcMap 10.5 environment. It involves (i) splitting compound lines into simple lines, (ii) editing lineaments attributes and (iii) exporting lineaments shape file. Next, lineaments density around each grid cell within a specific search distance was computed for generating lineament density map.

\subsubsection{Validation and fieldwork}

Shaded relief map and field observations were used for verification of lineament extraction results. Several structural studies used shaded relief maps to verify the results of lineament extraction (Adiri et al. 2017; Javhar et al. 2019). Shaded relief maps can provide useful sources for tectonic studies and the identification of regional structures (Masoud and Koike 2006). Analysis of the shaded relief image indicates that lineaments that are related to the boundaries between the shaded and unshaded areas can be visually identified (Masoud and Koike 2006; Saadi et al. 2011). Shaded relief images are generated from the digital elevation data in ArcMap software using the hillshade tool in spatial analyst. Several hill-shade maps with different solar azimuths were prepared, the North-South (N0) with a solar elevation of $45^{\circ}$ was chosen because the boundaries between the shaded and unshaded areas are plainly visible. The extracted lineaments are analyzed and evaluated by overlaying on the shaded relief maps. The visual interpretation shows that most of the obtained lineaments are mainly distributed between the shaded (high value) and unshaded (low value) areas, with the abrupt changes in slope and shading. In addition, some of the detected tectonic lineaments have been validated and confirmed by comparing with pre-existing documents such as faults present in the geological maps. Consequently, field observation was intended to verify the extracted lineaments that are appropriately related to geological structures.

\section{Results}

\subsection{Lithological, alteration and structural lineaments extraction}

Figure 3 shows RGB false color composite image of PC1 (Red), PC2 (Green) and PC3 (Blue) for the study area. An overview of lithological units in the study area and spectral discrimination of the Sebtide complex (metamorphic sequences), the Ghomaride complex (metasediments) and the Calcareous Dorsal Complex (carbonates and detrital sediments) are distinguishable. Typically, the Sebtide and Ghomaride complex are represented in purple color pixels with some admixture of green, cyan, red and yellow colors, whereas Calcareous Dorsal Complex is generally appeared in 
green to cyan shades. Carbonate and clay minerals contain spectral absorption features in the SWIR region due to the vibrational processes of the $\mathrm{CO}_{3}$ radical and $\mathrm{OH}$ combination bands (Pour et al. 2018b and references therein). Hence, the Calcareous Dorsal Complex shows different spectral characteristics compared to the other lithological complexes that are exposed in the study area.

For lineament extraction, the PC1 having high albedo attributable to the topographic features is considered. Figure 4 shows extracted lineaments in the PC1 image using four principal directional filters, including N-S, NE-SW, E-W and NW-SE. Results show that N-S trending lineaments are mostly mapped in the northern and southwestern parts of the study area (Figure $4 \mathrm{a}$ ), which are adjacent to the major fault and brittle zone systems such as the Fahies fault and Jebha-Chrafate fault, respectively, in the northern and southern sectors. In the northern part of the image, ductile structures depict complicated curvilinear features (several fold systems) are detected. NE-SW striking lineaments are slightly distributed in several parts of the study area and cuts the N-S lineaments (Figure 4 b) as younger lineament groups. E-W oriented lineaments are typically concentrated in the central north and south segments of the image (Figure $4 \mathrm{c}$ ), which could be linked to E-W to ENEWSW sinistral movement of the Jebha-Chrafate fault zone. NW-SE trending lineaments are strongly mapped in central and southern parts of the study area (Figure $4 \mathrm{~d}$ ). High concentration of lineaments represents brittle deformation events in the region that mostly strike NW-SE. Generally, most of the long lineaments are clustered in these zones.

Figure 5 shows OIF RGB color composite image of Band 5 (Red), Band 4 (Green) and Band 1 (Blue) for the study area. The main lithological units are mapped in the study area. The Sebtide and Ghomaride complex are typically appeared in read hue comprising some dark, blue and cyan pixels. The Calcareous Dorsal Complex is mapped as cyan tone. Comparison the results obtained from the OIF and PCA show nearly identical lithological discrimination performance. Analysis of eigenvector matrix derived from PCA indicates that the PC1 contains moderated negative loading in band 6 (0.28 ) and strong positive loading in band 7 (0.68). This PC has $82.70 \%$ of the total variance of seven bands (see Table 2). Therefore, the band ratio derived from PC1 can be considered as B6/B7, which has high potential to map clay minerals and carbonates (Rour et al. 2019). Similarly, PC2 and PC3 account for $12.69 \%$ and $3.57 \%$ of the total variance, respectively. The ratios of B7/B3 can be obtained from PC2 because of strong loadings in band 7 (-0.77) and band 3 (0.40) with opposite signs (see Table 2). The ferrous minerals such as olivine and pyroxenes can be mapped using band ratio $\mathrm{B} 7 / \mathrm{B} 3$ because they have high absorption on band $3(0.845-0.885 \mu \mathrm{m})$ due to $\mathrm{Fe}^{+2}$ absorption features (Pour et al. 2019). The band ratio of B2/B6 is achieved from PC3 due to a moderate contribution of band $2(-0.13)$ and strong loading in band $6(0.86)$ (see Table 2). Ferric iron oxide/hydroxide minerals such as hematite, jarosite and limonite have high absorption features in band 2 (Pour et al. 2019). According their difference in eigenvector loadings (positive and negative values) and identification of specific absorption features, this band composites can be considered the optimum band ratios for highlighting different alteration zones. In addition, the B6/B7, B7/B3 and B2/B6 combination band ratios as RGB false color composite may be able to map lithological units in the study area.

Figure 6 shows RGB color composite image derived from Band6/Band7 (Red), Band7/Band3 (Green) and Band2/Band6 (Blue) band ratio for the study area. High abundance of clay minerals and carbonates is mapped as red color zones in the study area. Green color zones show the spatial distribution of ferrous minerals. The distribution of iron oxide/hydroxides mineral is depicted as blue color. Yellow and magenta colors show the admixture of clay minerals and carbonates with ferrous minerals and ferric iron oxides, respectively (Figure 6). With reference to geology map of the study area, the Calcareous Dorsal Complex shows admixture of red, green and blue colors with low abundance of yellow and magenta color. However, the Sebtide complex and Ghomaride complexes contain high abundance of red, magenta and cyan pixels, predominantly located in north, northeastern and southern sectors of the study area. 
Extracted lineaments on the shaded relief of the study area is shown in Figure 7. This imagemap is generated by fusion of lineaments, lithologies and DEM information (extracted from PALSAR DEM and SRTM data). Lineaments in the study area are appropriately identified in Figure 7, which include the long lineaments and short lineaments that form linked systems with longer lineaments. The central and southern parts of the image exhibit longer lineaments compared to the northern part of the study area (Figure 7). Two major trends NW-SE and E-W are present mainly in whole of the study area. The northern and eastern segments of the image-map have few lineaments that strike N-S and NE-SW. Most longer lineaments strike NW-SE trending that are parallel to the Jebha-Chrafate fault zone system in the southern part of the study area. This NW-SE trend is like the orientation and sinistral movement of the Jebha-Chrafate fault zone (Figure 7).

\subsection{Lineament map for the study area}

Lineament density is defined as the total length of lineaments per unit area (Hung et al. 2005). This technique has been widely used as source of valuable information for lineament mapping (Hashim et al. 2013). For the study area, the lineament density map is produced as shown in Figure 8. It is used for a correlation analysis between the concentration of lineaments and the distribution of the faults existing in the geological maps of the study area. The resulting lineament density map shows a dominantly increased density towards the south and northern parts of the study area (Figure 8). The superposition of the extracted lineaments on the pre-existing faults in the geological maps of the study area and corresponding Rose diagram of the faults are depicted in Figure 9 (a) and (b). In the southern part, there is a high concentration of lineaments; this area is highly faulted and mainly occupied by several fault zones, namely Abyati and Tassart faults (Figure 9 a). In the northern part, the high density of lineaments is observable (see Figure 8), which is located adjacent to the Dar Eraai and Akouarene faults (Figure 9 a). The high density of lineaments is also more evident especially in the Triassic-Lower Jurassic sequence forming the essential and the more competent rocks of the Rifian Calcareous Dorsal units because they are identified as zones of high degree of rock fracturing/landslides. The Rose diagram of the pre-existing faults in the geological maps (Figure 9b) reveals the study area is dominated by the N040-050, N270-280, N280290, N305-320 and N350-360 directions of faults and fractures. NW-SE (N305-320 and N280-290) and W-E (N270-280) lineaments are the main directions and illustrate major faults in the study area. The second and third picks of lineaments are N-S (N350-360) and NE-SW (N040-050), which shows N-S and NE-SW trending faults and fractures.

Lineaments map, Rose diagram, fracture's trend and frequency diagrams are generated for study area by integrating the lineaments extracted from image processing techniques and existing geological maps (Figure 10 a-d). The lineaments map of the study area is shown in Figure 10 a. The results indicate the extracted lineaments by integration of image processing techniques are highly correlates with the existing faults in the geological maps (see Figure 9 a). However, it provides more detailed lineament features compared to the geological maps in the study area. After recognizing the most frequent directions in the Rose diagram (Figure $10 \mathrm{~b}$ ), the extracted fractures can be compared to those shown in the geological maps of the study area (e.g. Hashim et al. 2013; Adiri et al. 2017; Mhamdi et al. 2017; Javhar et al. 2019). Analysis of Rose diagram (Figure 10 b) for lineaments map shows analogous orientations for faults and fractures, which have been revealed for pre-existing faults in the geological maps (see Figure 9 b). Though N080-090 direction shows stronger pick compared to the Rose diagram of the pre-existing faults. Hence, W-E lineaments are better identified and mapped in the final lineaments map produced in this study (see Figure 10 a). Figure 10 (c) represents the frequency diagram of the fracture's trends. It shows the relative predominance of $130^{\circ}$ to $140^{\circ}$ and $90^{\circ}$ to $100^{\circ}$ intervals. Many other orientations having less prominent directions revealed the high complexity of the geological structures in the study area. The statistical analysis of the lineament is presented in Figure 10 (d). The number of 480 geological lineaments are identified and extracted. The values of the lineament length range from $67 \mathrm{~m}$ to a 
maximum of $2770 \mathrm{~m}$ are found. The most abundant lineament lengths are between 400 to $800 \mathrm{~m}$, which includes $47 \%$ of the total number extracted lineaments in the study area.

\subsection{Field observations}

Figure 11 (P1-P13) shows some field photograph of extracted lineaments in different locations of the study area, which are verified during comprehensive field investigations. The Zarka fault oriented E-W to ESE-WNW is investigated. It is located almost between the Calcareous Dorsal and Ghomarides complex that affecting the Triassic-Liasic carbonates. The Zarka fault appears as a very steep fault and shows a sinistral component (Figure 11 P1). The NE-SW Dar Zkiyek fault delimiting the western border of the Dar Zkiyek ridge as a dextral lateral ramp is observed. It is reactivated into a normal fault (Figure 11 P2). The NW-SE Jbel Bourja fault is affected the Triassic-Liasic carbonates. It is responsible for the transverse displacement with a right-lateral offset of more than 20m (Figure 11 P3). The E-W Dar Eraai sinistral strike-slip fault, which represents a lateral ramp crosscutting the entire tectonic stack of units of the Calcareous Dorsal Complex. The minimum sinistral displacement of the fault zone is estimated at $8 \mathrm{~km}$ (Figure 11 P4).

Figure 11 P5 shows the NW-SE Akouarene fault, which is emphasized by slices and tectonic horses of Triassic-Liasic carbonates, where develops steep fault planes and shows sinistral kinematic indicators. Tellouja fault is a curvilinear accident oriented roughly NW-SE, observed in the TriassicLiasic carbonates (Figure 11 P6). It extends for a long-distance, that extends over $4 \mathrm{~km}$, and cuts all the imbricate tectonic units' system of the Calcareous Dorsal Complex (Figure 11 P6). The N-S Koudiet Aglaguel reverse fault affecting the Tertiary detrital sediments, its direction is parallel to the direction of the tectonic units boundaries of the Calcareous Dorsal Complex (Figure 11 P7). Figure 11 P8 shows the whole tectonic stack of a unit of the Calcareous Dorsal Complex, which is represented by Triassic-Liasic carbonates and Tertiary detrital sediments. It crosscuts transversely by E-W Jamaa El Karn sinistral strike-slip fault (Figure 11 P8). The NW-SE El Ouadiyine fault affecting the Triassic-Liasic carbonates as a sinistral strike slip fault is shown in Figure 11 P9.

The Tassart fault oriented NW-SE with a SW dip that is observed in the Triassic-Liasic carbonates, which has a sinistral component (Figure 11 P10). The N-S Baya reverse fault affecting the Tertiary detrital sediments, its direction is parallel to the direction of the tectonic units boundaries of the Calcareous Dorsal Complex (Figure 11 P11). The NW-SE Abyati fault is observed in the Triassic-Liasic carbonates that extends over $10 \mathrm{~km}$ (Figure $11 \mathrm{P} 12$ ). It has a high dip and a main sinistral displacement. It crosscuts all the imbricate tectonic units' system of the Calcareous Dorsal Complex (Figure 11 P12). The E-W Tamalout strike-slip fault is located in the Triassic-Liasic carbonates of the Calcareous Dorsal Complex. It shows a sinistral component (Figure 11 P13). Furthermore, it is important to note the predominance of the NW-SE and the E-W directions, which were also reported in several previous structural studies carried out in the study region (Hlila and Sanz de Galdeano 1994; Michard et al. (2002); Vitale et al. 2014a, 2014b, 2015).

\section{Discussion}

Tectonic lineaments are extracted using the remote sensing image processing techniques and GIS approach in the internal segment of North-Western Rif belt, Morocco. Results show that the main lineaments are oriented E-W and NW-SE. However, N-S and NE-SW trending lineaments are also mapped in the study area. According to previous studies, the Rifian Internal Domain is characterized by tectonic structures such as thrusts, reverse and strike-slip faults (Vitale et al. 2014a, 2014b, 2015). The fractures trending E-W are statistically more frequent as mentioned above and fractures with similar direction are mapped in Tetouan-Ras Mazari and Souk Larbaa Beni Hessane as transversal strike-slip faults with a sinistral component that crosscutting a wide zone of the 
Calcareous Dorsal Complex (e.g. Dar Eraai fault). They were generally associated with the westward displacement of the tectonic units (El Adraoui et al. 2007). More southward, a sinistral transcurrent main fault oriented ENE-SSW to E-W and bordering the entire internal domain (i.e. the Jebhachrafate fault) (e.g. Andrieux et al. 1971; Olivier 1982; Benmakhlouf et al. 2005). North of Tetouan, there are different scales faults trending E-W affecting the Calcareous Dorsal Complex and the most important one is the sinistral transcurrent "Semsa fault" which appear strictly north of Tetouan city (Hlila and Sanz de Galdeano 1995; El Adraoui et al. 2007). The fractures trending NW-SE, statistically abundant as is the case with the first type of fractures, are well manifested in the entire internal domain as marked in the 1/50000 geological maps of the Northern internal Rif. South of Tetouan city, they are well represented in the Calcareous Dorsal Complex and they have generally a sinistral strike-slip component. Indeed, a good example of this set of faults in the study area corresponds to the Abyati fault, that extends over $10 \mathrm{~km}$, which is interpreted as a multi-kilometer lateral ramp of westward verging thrust systems.

With regard to N-S oriented fractures, they generally correspond in the study area to reverse faults and thrusts as their direction is parallel to the direction of the tectonic units boundaries of the Calcareous Dorsal Complex and orthogonal to the westward verging thrusts between tectonic slices. The NE-SW trending fractures are well developed in the Rifian Calcareous Dorsal north of Tetouan city and represented by many transcurrent faults. The major Fahies fault is a good example of this set of fractures, which extends over $15 \mathrm{~km}$. They correspond to dextral strike slip faults forming with NW-SE trending fault, a conjugate system associated with an E-W compressive tectonic event during the Early-Middle Miocene (e.g. Hlila and Sanz de Galdeano 1994, 1995; EL Adraoui et al. 2007). In the south of Tetouan (the oued laou valley area), Hlila et al. (2014a, b) described two kilometric conjugate NE-SW trending normal faults resulting in graben structure and the opening an intramountain basin in the Pliocene (e.g. Tirinesse basin). Finally, several authors highlighted the importance of these kind of fractures during the mio-pliocene and quaternary in the structuring and the tectonic of the Rifian belt chain (Ait Brahim and Sossey Alaoui 2002; Ait Brahim et al. 2002; Tahayt et al. 2008).

\section{Conclusions}

The methodology used in this study allows the identification of the linear structures and facilitates geological mapping structures in a complex zone that covers a wide, largely inaccessible geographical area. Different processing techniques, including the PCA, OIF, band ratios, and directional filters were applied to Landsat 8 OLI data for this purpose. Thereafter, the obtained results were compared to the existing geological maps and detailed field investigations.

- 480 structural lineaments are identified and mapped in the study region, which are mostly classified into four fracture systems trending NW-SE, N-S, NE-SW, and E-W.

- The dominated directions were the NW-SE and the E-W, which are the Fahies and Jebha-Chrafate fault systems in the northern and southern sectors of the study region.

- The Rose diagram of the lineaments mapped in this study reveals the N040-050, N080090, N270-280, N280-290, N305-320 and N350-360 directions of faults and fractures. NW-SE (N305-320 and N280-290) and W-E (N270-280 and N080-090) lineaments are the main directions and illustrate major faults in the study area. The second and third picks of lineaments are N-S (N350-360) and NE-SW (N040-050), showing N-S and NE-SW trending faults and fractures. Analysis of Rose diagram for lineaments map shows analogous orientations for faults and fractures, which have been revealed for preexisting faults in the geological maps. However, N080-090 direction shows stronger pick compared to the Rose diagram of the pre-existing faults. Hence, W-E lineaments are better identified and mapped in the final lineaments map produced in this study. 
In this research, the integration of remote sensing imagery and GIS techniques highlights its efficiency and reliability in the complex zone, not only mapping out the lineament features in the study area but also updating existing geological maps of the area. The applied approach can be considered as a low-cost/integrated GIS and remote sensing technique for mapping ore mineralizations, exploring oil, gas and groundwater and mitigating of natural hazard, where fieldwork is constrained by terrain conditions.

\section{Acknowledgments}

The Laboratoire de Géologie de l'Environnement, Département de Géologie, Faculté des Sciences, Université Abdelmalek Essaâdi, Tetouan and departamento de Ciencias de la Tierra y Medio Ambiente, Fac. Ciencias, Universidad de Alicante are acknowledged. The Institute of Oceanography and Environment (INOS), Universiti Malaysia Terengganu (UMT) is also acknowledged for providing required facilities for re-writing and revising this manuscript.

\section{References}

Abdelkareem M, El-Baz F. 2015. Analyses of optical images and radar data reveal structural features and predict groundwater accumulations in the central eastern desert of Egypt. Arab.J.Geosci. $8,2653-2666$.

Abdelkareem M., Abdullah O. Bamousa, Zakaria Hamimi., Gamal M. Kamal El-Din. 2020. Multispectral and RADAR images integration for geologic, geomorphic, and structural investigation in southwestern Arabian Shield, Al Qunfudhah area, Saudi Arabia. Journal Of Taibah University For Science 14, NO. 1, 383-401.

Adiri Z, El Harti A, Jellouli A, Lhissou R, Maacha L, Azmi M, Zouhair M, Bachaoui EM. 2017. Comparison of Landsat-8, ASTER and Sentinel 1 satellite remote sensing data in automatic lineaments extraction: A case study of Sidi Flah-Bouskour inlier, Moroccan Anti Atlas. Advances in Space Research. 60(11):2355-2367.

Ahmadirouhani R, Rahimi B, Karimpour MH, Shafaroudi AM, Najafi SA, Pour AB. 2017. Fracture mapping of lineaments and recognizing their tectonic significance using SPOT-5 satellite data: A case study from the Bajestan area, Lut Block, east of Iran. Journal of African Earth Sciences. 134:600-612.

Ait Brahim L, Chotin P, Hinaj S, Abdelouafi A, El Adraoui A, Nakcha C, Dhont D, Charroud M, Sossey Alaoui F, Amrhar M, Bouaza A, Tabyaoui H, Chaouni A. 2002. Paleostress evolution in the Moroccan African margin from Triassic to Present. Tectonophysics. 357:187-205.

Ait Brahim L, Sossey Alaoui F. 2002. Utilisation de la télédétection pour l'analyse de la fracturation du domaine interne rifain (Maroc) : relation avec la répartition des sources. Télédétection. 22:123-135. https://doi.org/10.1051/matecconf/201814902084.

Al-Djazouli MO, Elmorabiti K, Zoheir B, Rahimi A, Amellah O. 2019. Use of Landsat-8 OLI data for delineating fracture systems in subsoil regions: implications for groundwater prospection 
in the Waddai area, eastern Chad. Arabian Journal of Geosciences. 12(7):241. https://doi.org/10.1007/s12517-019-4354-8.

Alizadeh M, Ngah I, Hashim M, Pradhan B, Pour AB. 2018. A Hybrid Analytic Network Process and Artificial Neural Network (ANP-ANN) Model for Urban Earthquake Vulnerability Assessment. Remote Sensing. 10(6):975.

Amri K, Mahdjoub Y, Guergour L. 2011. Use of Landsat 7 ETM+ for lithological and structural mapping of Wadi Afara Heouine area (Tahifet-Central Hoggar, Algeria). Arabian journal of geosciences. 4(7-8):1273-1287.

Andrieux J, Fontbote JM, Mattauer M. 1971. Sur un modèle explicatif de l'arc de Gibraltar. Earth Planet. Sci. Lett. 12:191-198.

Andrieux J, Mattauer M. 1973. Précisions sur un modèle explicatif de l'Arc de Gibraltar. Bull. Soc. Géologique Fr. 7:115-118.

Azar APK, Askari G, Crispini L, Pour AB, Zoheir B, Pradhan B. 2019. Field and spaceborne imagery data for evaluation of the paleo-stress regime during formation of the Jurassic dike swarms in the Kalateh Alaeddin Mountain area, Shahrood, north Iran. Arabian Journal of Geosciences. 12(17):552.

Benmakhlouf M, Galindo-Zaldívar J, Chalouan A, Sanz de Galdeano C, Ahmamou M, LópezGarrido A. 2005. Cinemática y paleoesfuerzos en la zona de falla transcurrente de JebhaChrafate (Rif septentrional, Marruecos). Geogaceta. 38:71-74.

Biju-Duval B, Rivereau JC, Lamperein C, Lopez N. 1976. Esquisse photogéologique du domaine Méditerranéen. Grands traits structuraux à partir des images du satellite Landsat-1. Commentaires. Revue de l'Institut Français du Pétrole. 31(3):365-400.

Borra S, Thanki R, Dey N. 2019. Satellite Image Analysis: Clustering and Classification. Singapore: Springer.

Bouillin JP, Durand-Delga M, Olivier P. 1986. Betic-Rifian and Tyrrhenian arcs: distinctive features, genesis and development stages. In Developments in Geotectonics. 21:281-304.

Chalouan A, Michard A. 2004. The Alpine Rif Belt (Morocco): a case of mountain building in a subduction-subduction-transform fault triple junction. Pure and applied Geophysics. 161(3):489-519.

Chalouan A, Michard A, El Kadiri K, Negro F, De Lamotte F, Soto J I, Saddiqi O. 2008. The Rif belt. In: Michard A, Saddiqi O, Chalouan O, De Lamotte F, Eds. Continental evolution: The geology of Morocco; Structure, stratigraphy and tectonics of the Africa-AtlanticMediterranean triple junction. Berlin: Springer; p. 203-302. 
Chalouan A, Michard A, Feinberg H, Montigny R, Saddiqi O. 2001. The Rif mountain building (Morocco); a new tectonic scenario. Bulletin de la Société géologique de France. 172:603616.

Chavez P, Berlin GL, Sowers LB. 1982. Statistical method for selecting landsat MSS. J Appl Photogr Eng. 8:23-30.

Corgne S, Magagi R, Yergeau M, Sylla D. 2010. An integrated approach to hydro-geological lineament mapping of a semi-arid region of West Africa using Radarsat-1 and GIS. Remote Sensing of Environment. 114:1863-1875.

Durand-Delga M. 1972. La courbure de Gibraltar, extrémité occidentale des chaînes alpines, unit l'Europe et l'Afrique. Eclogae Geol Helv. 65:267-278.

Durand-Delga M. 1980. La Méditerranée occidentale, étape de sa genèse et problèmes structuraux liés à Celles-ci. Mem H Ser Soc Geol Fr. 10:203-224.

Durand-Delga M, Kornprobst J. 1963. Esquisse géologique de la région de Ceuta (Maroc). Bulletin de la Société Géologique de France. 7(7):1049-1057.

Durand-Delga M, Olivier P. 1988. Evolution of the Alboran block margin from early Mesozoic to early Miocene time. In: V.H. Jacobshagen, Editor. Geology of the Northwest African Continental Margin. Berlin: Springer-Verlag; p. 3-20.

El Adraoui A, Ait Brahim L, Sanz de Galdeano C. 2007. Fallas de salto en dirección en el Haouz meridional (Complejo de la Dorsal, Rif interno, $\mathrm{N}$ de Tetuán, Marruecos). Comparación con las Béticas (España). Geogaceta. 41:71-74.

El Kadiri K, Linares A, Oloriz F. 1992. La Dorsale calcaire rifaine (Maroc septentrional): Evolution stratigraphique et géodynamique durant le Jurassique-Crétacé. Notes et Mémoires du Service Géologique du Maroc. 336:217-265.

Eldosouky AM, Abdelkareem M, Elkhateeb SO. 2017. Integration of remote sensing and aeromagnetic data for mapping structural features and hydrothermal alteration zones in Wadi Allaqi area, South Eastern Desert of Egypt. J Afr Earth Sci. 130:28-37.

Fallot P. 1937. Essai sur la géologie du Rif septentrional. Notes et Mémoires du Service Géologique du Maroc. 40:1-548.

Griffon JC. 1966. La Dorsale calcaire au sud de Tetouan. Notes et Mémoires du Service Géologique du Maroc. 184:149-223.

Guerrera F, Martín-Algarra A, Perrone V. 1993. Late Oligocene-Miocene syn-/-late-orogenic successions in western and central Mediterranean chains from the Betic Cordillera to the southern Apennines. Terra Nova. 5:525-544. 
Hamdani N, Baali A. 2019. Fracture network mapping using Landsat 8 OLI data and linkage with the karst system: a case study of the Moroccan central middle Atlas. Remote Sensing in Earth Systems Sciences. 2(1):1-17.

Hamdani N, Baali A. 2020. Characterization of groundwater potential zones using analytic hierarchy process and integrated geomatic techniques in Central Middle Atlas (Morocco). Applied Geomatics. 1-13. https://doi.org/10.1007/s12518-020-00300-z.

Hamimi Z, El-Fakharani A, Emam A, Barreiro JG, Abdelrahman E, Abo-Soliman MY. 2018. Reappraisal of the kinematic history of Nugrus shear zone using PALSAR and microstructural data: implications for the tectonic evolution of the Eastern Desert tectonic terrane, northern Nubian Shield. Arabian Journal of Geosciences. 11(17):494. DOI:10.1007/s12517-018-3837-3.

Hashim M, Ahmad S, Johari MAM, Pour AB. 2013. Automatic lineament extraction in a heavily vegetated region using Landsat Enhanced Thematic Mapper (ETM+) imagery. Adv Space Res. 51:874-890.

Hlila R, Sanz de Galdeano C. 1994. Structure de la chaîne calcaire du Haouz (Rif interne, Maroc). Interprétation et aspects chronologiques. Comptes Rendus Académie Sci Sér 2 Sci Terre Planètes. 318:1261-1266.

Hlila R, Sanz de Galdeano C. 1995. Structure, cinématique et chronologie des déformations dans la dorsale du Haouz (Rif, Maroc). Geogaceta. 17:95-97.

Hlila R, Sanz de Galdeano C, El Kadiri K, Guerra Merchán A, Serrano Lozano F. 2014a. Subsidence and uplift during the Plio-Quaternary in the Oued Laou and Tirinesse sectors (internal Rif, Morocco). Geogaceta. 56:35-38.

Hlila R, Sanz de Galdeano C, El Kadiri K, Guerra-Merchán A, Serrano Lozano F. 2014b. The early Pliocene Tirinesse basin (SW of Oued Laou, Rif, Morocco): proposal of a formation model. Geogaceta. 56:31-34.

Hosseini S, Lashkaripour GR, Moghadas NH, Ghafoori M, Pour BA. 2019. Lineament mapping and fractal analysis using SPOT-ASTER satellite imagery for evaluating the severity of slope weathering process. Advances in Space Research. 63(2):871-885.

Hung LQ, Batelaan O, De Smedt F. 2005. Lineament extraction and analysis, comparison of LANDSAT ETM and ASTER imagery. Case study: Suoimuoi tropical karst catchment, Vietnam. Remote Sensing for Environmental Monitoring, GIS Applications, and Geology. 5983:59830T. https://doi.org/10.1117/12.627699.

Irons JR, Dwyer JL, Barsi JA. 2012. The next Landsat satellite: The Landsat data continuity mission. Remote Sensing of Environment. 122:11-21. 
Igarashi T. 2001. ALOS Mission requirement and sensor specifications. Advances in Space Research 28(1), 127-131.

Javhar A, Chen X, Bao A, Jamshed A, Yunus M, Jovid A, Latipa T. 2019. Comparison of multiresolution optical Landsat-8, Sentinel-2 and radar Sentinel-1 data for automatic lineament extraction: A case study of Alichur area, SE Pamir. Remote Sensing 11(7):778. https://doi.org/10.3390/rs11070778.

Jensen JR. 2015. Introductory Digital Image Processing: A Remote Sensing Perspective. Upper Saddle River, NJ, USA: $4^{\text {th }}$ ed. Prentice Hall Press.

Kamal El-Din, G., Abdelkareem M. 2018. Integration of remote sensing, geochemical and field data in the Qena-Safaga shear zone: implications for structural evolution of the easterndesert Egypt. J.Afr.Earth.Sci. 141,179-193.

Kornprobst J. 1974. Contributions à l'étude pétrographique et structurale de la zone interne du Rif (Maroc septentrional). Notes et Mémoires du Service Géologique du Maroc. 251:1-226.

Leblanc D, Olivier P. 1984. Role of strike-slip faults in the Betic-Rifian orogeny. Tectonophysics. 101(3-4):345-355.

Majumdar TJ, Bhattacharya AK. 2007. ERS-2 SAR and IRS-1C LISS III data fusion: a PCA approach to improve remote sensing based geological interpretation. ISPRS Journal of Photogrammetry and Remote Sensing. 61:281-297.

Majumdar TJ, Bhattacharya BB. 1988. Application of the Haar transform for extraction of linear and anomalous patterns over a part of Cambay basin, India. Remote Sensing Letters International Journal of Remote Sensing. 9(12):1937-1942.

Marion A. 1987. Introduction aux techniques de traitement d'images. Paris: Eyrolles.

Masoud A, Koike K. 2006. Tectonic architecture through Landsat-7 ETM+/SRTM DEM derived lineaments and relationship to the hydrogeologic setting in Siwa region, NW Egypt. Journal of African Earth Sciences. 45(4-5):467-477.

Masoud A, Koike K. 2017. Applicability of computer-aided comprehensive tool (LINDA: LINeament Detection and Analysis) and shaded digital elevation model for characterizing and interpreting morphotectonic features from lineaments. Computers and Geosciences. 106:89-100.

Mhamdi HS, Raji M, Maimouni S, Oukassou M. 2017. Fractures network mapping using remote sensing in the Paleozoic massif of Tichka (Western High Atlas, Morocco). Arab J Geosci. 10(5):125. https://doi.org/10.1007/s12517-017-2912-5.

Michard A, Chalouan A. 1991. The Ghomarides nappes, rif coast range, Morocco: an african terrane in the West Mediterranean alpine belt. Bulletin of the Geological Society of Greece. 25:117129. 
Michard A, Chalouan A, Feinberg H, Goffé B, Montigny R. 2002. How does the Alpine belt end between Spain and Morocco?. Bull Société Géologique Fr. 173:3-15.

Michard A, Negro F, Saddiqi O, Bouybaouene ML, Chalouan A, Montigny R, Goffé B. 2006. Pressure-temperature-time constraints on the Maghrebide mountain building: evidence from the Rif-Betic transect (Morocco, Spain), Algerian correlations, and geodynamic implications. Comptes Rendus Geoscience. 338:92-114.

Milliard Y. 1959. Les massifs métamorphiques et ultrabasiques de la zone paléo-zoïque interne du Rif. Notes et Mémoires du Service Géologique du Maroc. 18:125-160.

Moradpour H, Rostami Paydar G, Pour AB, Kamran KV, Feizizadeh B, Muslim AM, Hossain MS. 2020. Landsat-7 and ASTER remote sensing satellite imagery for identification of iron skarn mineralization in metamorphic regions, Geocarto International, DOI: $10.1080 / 10106049.2020 .1810327$

Nikolakopoulos KG, Kamaratakis EK, Chrysoulakis N. 2006. SRTM vs ASTER elevation products. Comparison for two regions in Crete, Greece. International Journal of Remote Sensing. 27 (21).

Nold M, Uttinger J, Wildi W. 1981. Géologie de la Dorsale calcaire entre Tetouan et Assifane (Rif interne, Maroc). Notes et Mémoires du Service Géologique du Maroc. 233:1-233.

Olivier P. 1982. L'accident de Jebha-Chrafate (Rif, Maroc). Rev Géol Dyn Géogr Phys. 23:97-106.

Ouko C, Mutua F, Mwaniki M. 2018. A Pre-exploration Technique for Mapping Petroleum Potential Areas Based on Induced Surface Alterations and Possible Traps. Universal Journal of Geoscience. 6 (5):158-174. doi: 10.13189/ujg.2018.060503.

Pandey P, Sharma L. 2019. Image processing techniques applied to satellite data for extracting lineaments using PCI Geomatica and their morphotectonic interpretation in the parts of northwestern Himalayan frontal thrust. Journal of the Indian Society of Remote Sensing. 47(5):809-820. https://doi.org/10.1007/s12524-019-00962-2.

Pour AB, Hashim M. 2017. Application of Landsat-8 and ALOS-2 data for structural and landslide hazard mapping in Kelantan, Malaysia. Natural Hazards and Earth System Sciences. 17 (7):1285-1303.

Pour AB, Hashim M, Makoundi C, Zaw K. 2016. Structural Mapping of the Bentong-Raub Suture Zone Using PALSAR Remote Sensing Data, Peninsular Malaysia: Implications for Sediment-hosted/Orogenic Gold Mineral Systems Exploration. Resource Geology. 66(4):368-385.

Pour AB, Hashim M, Park Y. 2018a. Gondwana-Derived Terranes structural mapping using PALSAR remote sensing data. J Indian Soc Remote. 46(2):249-262. 
Pour AB, Park TS, Park Y, Hong JK, Zoheir B, Pradhan B, Ayoobi I, Hashim M. 2018b. Application of multi-sensor satellite data for exploration of $\mathrm{Zn}-\mathrm{Pb}$ sulfide mineralization in the Franklinian Basin, North Greenland. Remote Sens. 10(8):1186.

Pour AB, Park Y, Park TS, Hong JK, Hashim M, Woo J, Ayoobi I. 2019. Evaluation of ICA and CEM algorithms with Landsat-8/ASTER data for geological mapping in inaccessible regions. Geocarto International 34, 785-816.

Radaideh OMA, Grasemann B, Melichar R, Mosar J. 2016. Detection and analysis of morphotectonic features utilizing satellite remote sensing and GIS: An example in SW Jordan. Geomorphology. 275:58-79.

Raharimahefa, T., Kusky, T.M. (2009). Structural and remote sensing analysis of the Betsimisaraka Suture in northeastern Madagascar. Gondwana Reseach 15, 14-27.

Rahman M, Ullah R, Lan M, Sri Sumantyo J, Kuze H, Tateishi R. 2013. Comparison of Landsat image classification methods for detecting mangrove forests in Sundarbans. Int J Remote Sens. 34:1041-1056. https://doi.org/10.1080/01431161.2012.717181.

Richards JA. 1999. Remote Sensing Digital Image Analysis. Berlin, Germany: Springer-Verlag.

Robert A. 1997. Remote sensing, models and methods for image processing. Academic Press. 2:229286.

Saadi NM, Zaher MA, El-Baz F, Watanabe K. 2011. Integrated remote sensing data utilization for investigating structural and tectonic history of the Ghadames Basin, Libya. International Journal of Applied Earth Observation and Geoinformation. 13(5):778-791.

Saddiqi O, Feinberg H, El Azzab D, Michard A. 1995. Paléomagnétisme des péridotites des Beni Bousera (Rif interne, Maroc) : conséquences pour l'évolution miocène de l'Arc de Gibraltar. Comptes Rendus Académie Sci. Sér. 2 Sci. Terre Planètes. 321:361-368.

Sekandari M, Masoumi I, Beiranvand Pour AM, Muslim A, Hossain MS, Misra A. 2020. ASTER and WorldView-3 satellite data for mapping lithology and alteration minerals associated with $\mathrm{Pb}-\mathrm{Zn}$ mineralization. Geocarto Int. DOI:10.1080/10106049.2020.1790676

Solomon S, Ghebreab W. 2006. Lineament characterization and their tectonic significance using Landsat TM data and field studies in the central highlands of Eritrea. J Afr Earth Sci. 46:371378. https://doi.org/10.1016/j.jafrearsci.2006.06.007.

Tahayt A, Mourabit T, Rigo A, Feigl KL, Fadil A, Mcclusky S, Reilinger R, Serroukh M, OuazzaniTouhami A, Bensari D, Vernant Ph. 2008. Mouvements actuels des blocs tectoniques dans l'arc Bético-Rifain à partir des mesures GPS entre 1999 et 2005. Comptes Rendus Geoscience. 340(6):400-413.

Takodjou Wambo JD, Ganno S, Djonthu Lahe YS, Kouankap Nono GD, Fossi DH, Tchouatcha MS, Nzenti JP. 2018. Geostatistical and GIS analysis of the spatial variability of alluvial gold 
content in Ngoura-Colomines area, Eastern Cameroon: Implications for the exploration of primary gold deposit. Journal of African Earth Sciences. 142:138-157.

van der Pluijm BA, Marshak S. 1997. Earth Structure - An Introduction to Structural Geology and Tectonics. WCB-McGraw-Hill.

Vitale S, Zaghloul MN, El Ouaragli B, Tramparulo FD, Ciarcia S. 2015. Polyphase deformation of the Dorsale Calcaire Complex and the Maghrebian Flysch Basin Units in the Jebha area (Central Rif, Morocco): New insights into the Miocene tectonic evolution of the Central Rif belt. J Geodyn. 90:14-31. https://doi.org/10.1016/j.jog.2015.07.002.

Vitale S, Zaghloul MN, Tramparulo FD, El Ouaragli B. 2014a. Deformation characterization of a regional thrust zone in the northern Rif (Chefchaouen, Morocco). J Geodyn. 77:22-38. https://doi.org/10.1016/j.jog.2013.09.006.

Vitale S, Zaghloul MN, Tramparulo FD, El Ouaragli B, Ciarcia S. 2014b. From Jurassic extension to Miocene shortening: an example of polyphasic deformation in the external Dorsale Calcaire unit (Chefchaouen, Morocco). Tectonophysics. 633:63-76.

Wildi W, Nold M, Uttinger J. 1977. La Dorsale calcaire entre Tetouan et Assifane (Rif interne, Maroc). Eclogae Geologicae Helvetiae. 70(2):371-415. 

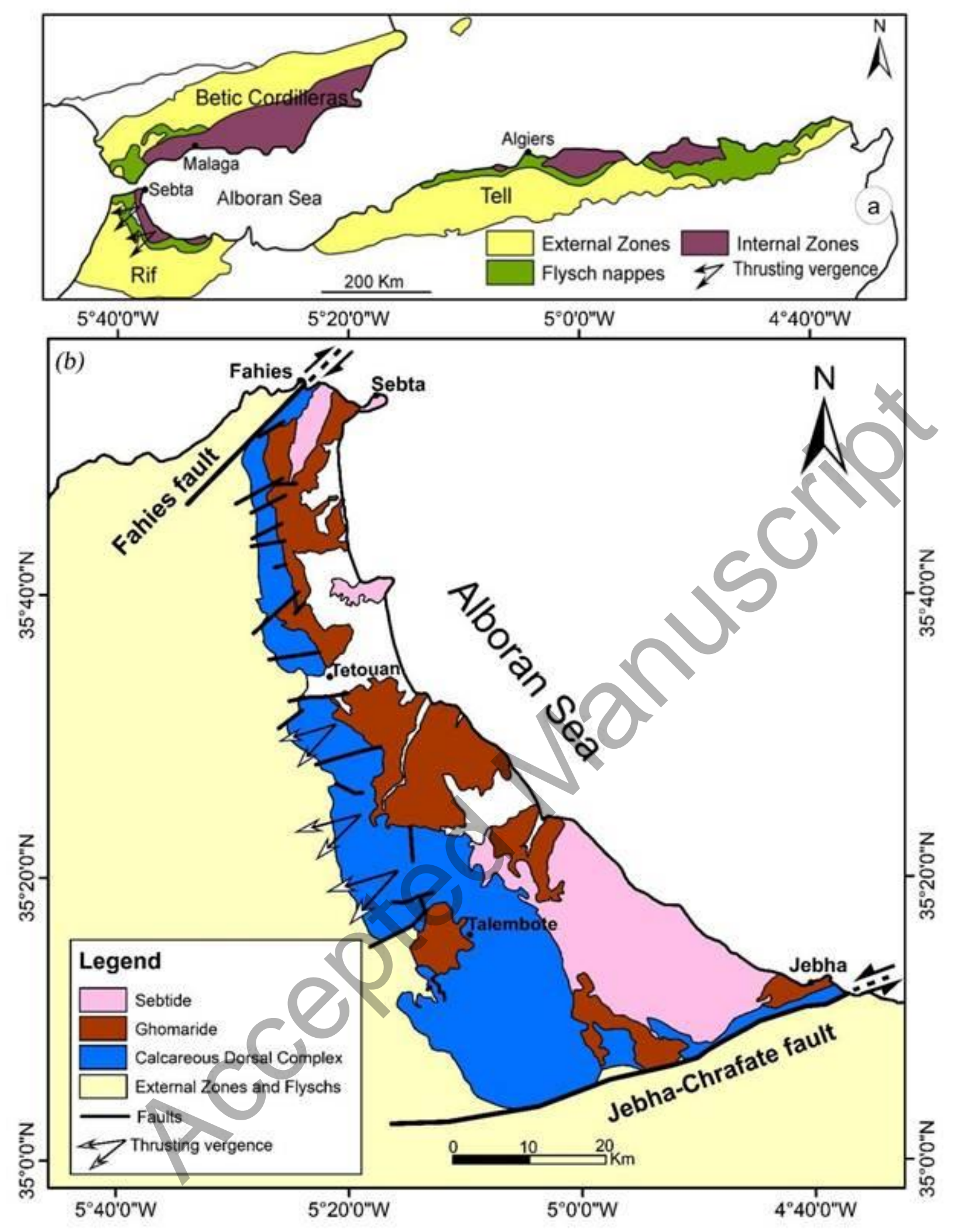

Figure 1. (a) simplified geology map of West Mediterranean chains (after Durand-Delga et al., 2000, modified), (b) geology map of northern west Rif and selected zone in this study. 


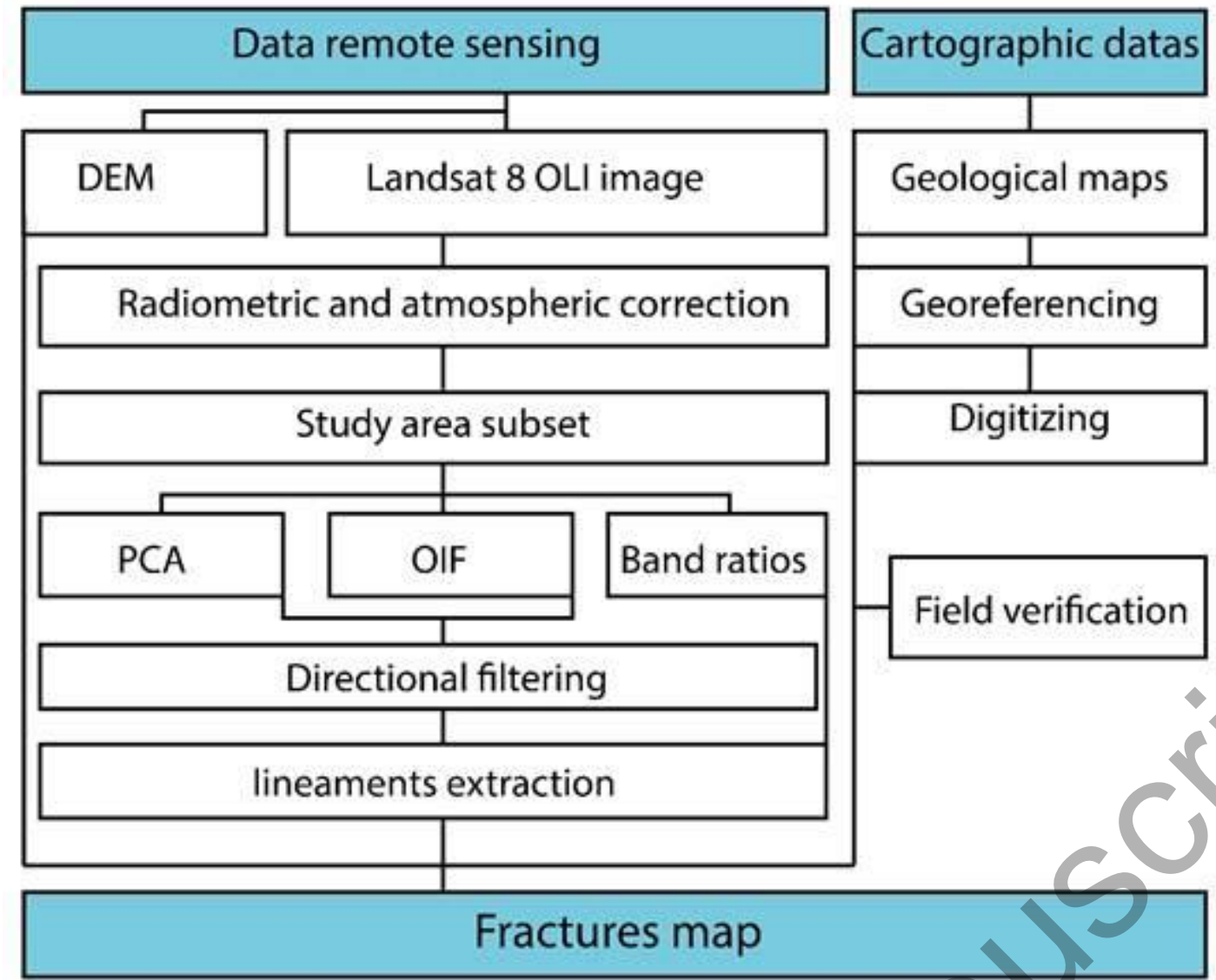

Figure 2. The methodological flowchart used in this study 


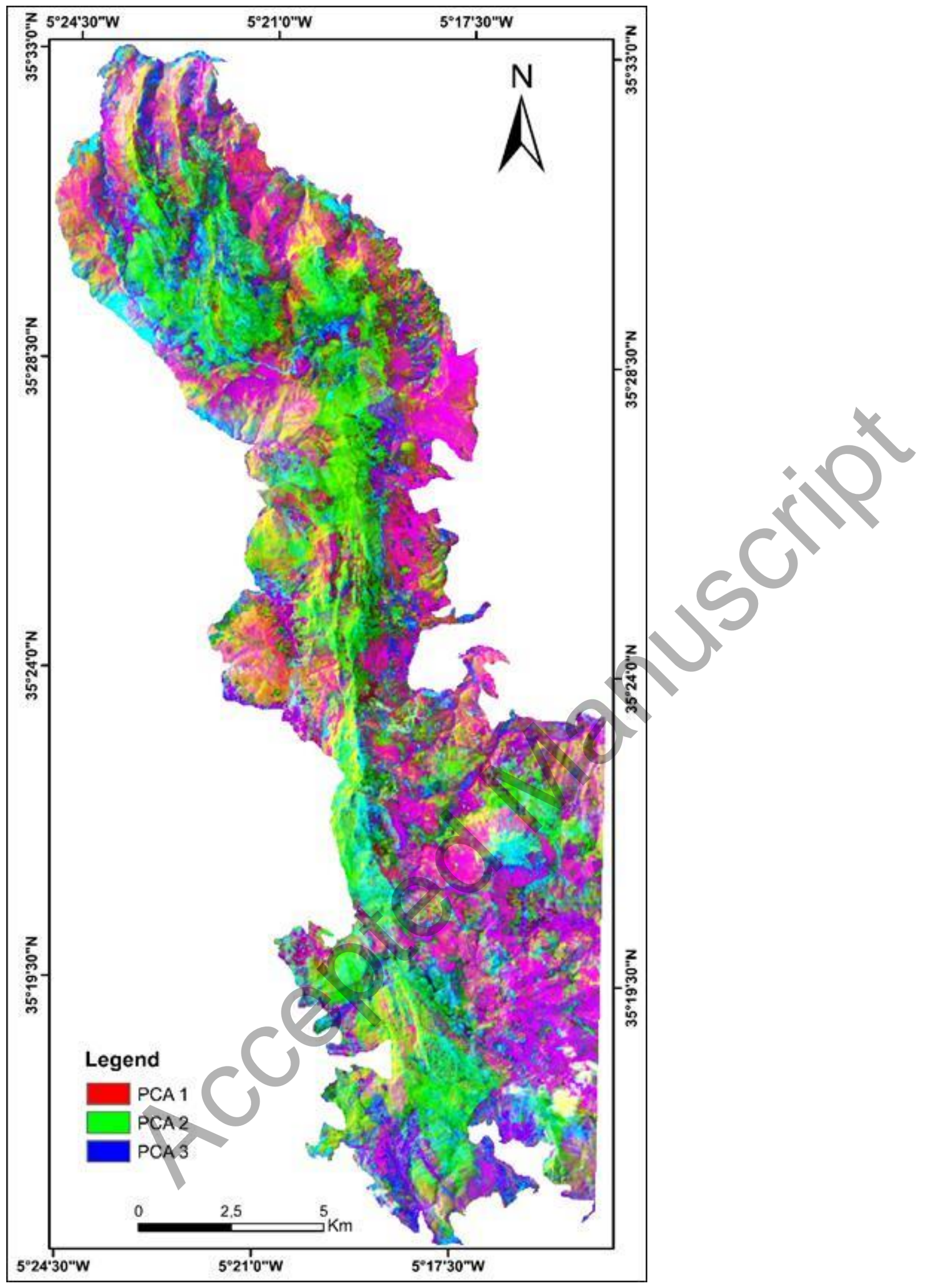

Figure 3. RGB false color composite of the PC1 (Red), PC2 (Green) and PC3 (Blue) for the study area. The main lithological units are mapped and discriminated. 


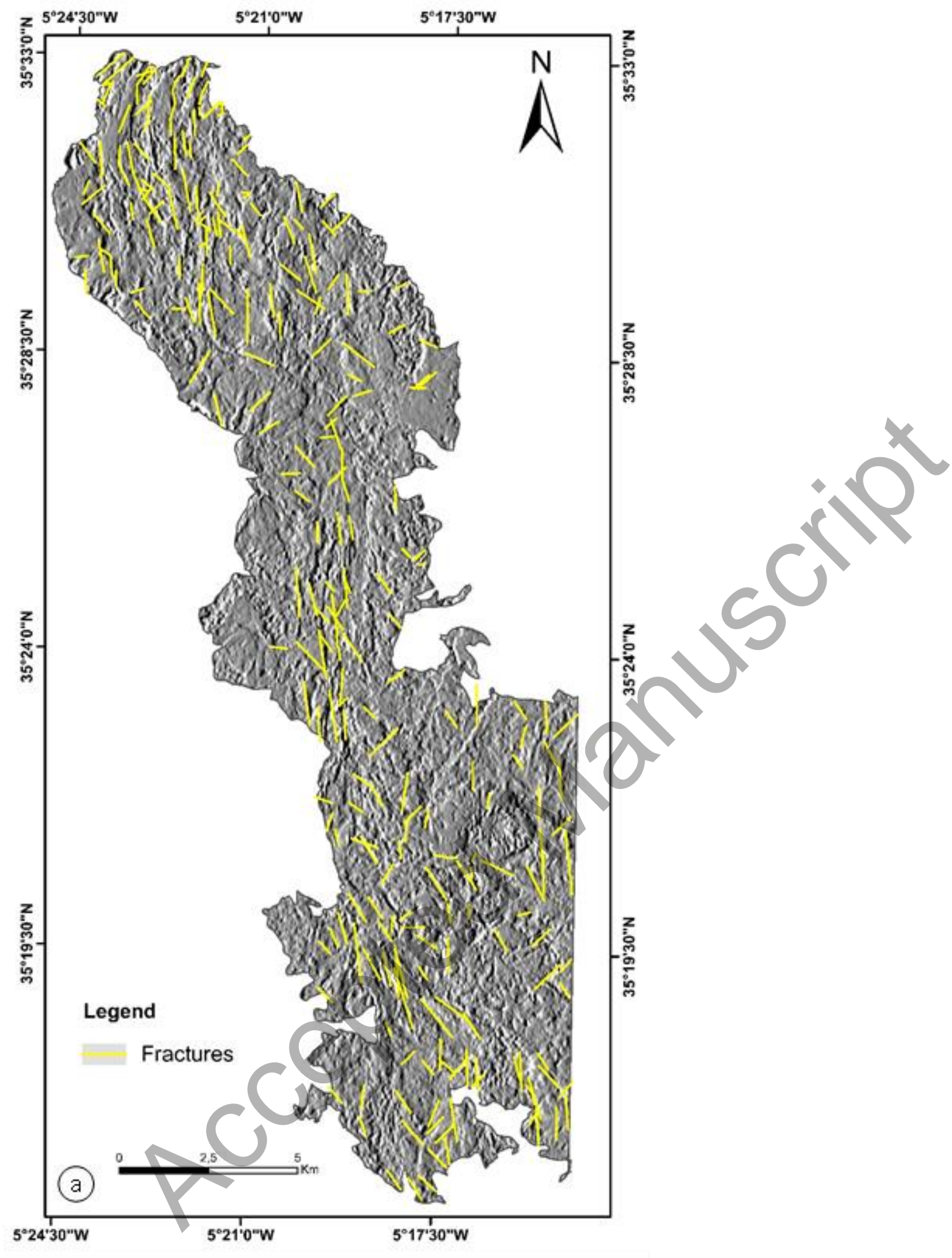




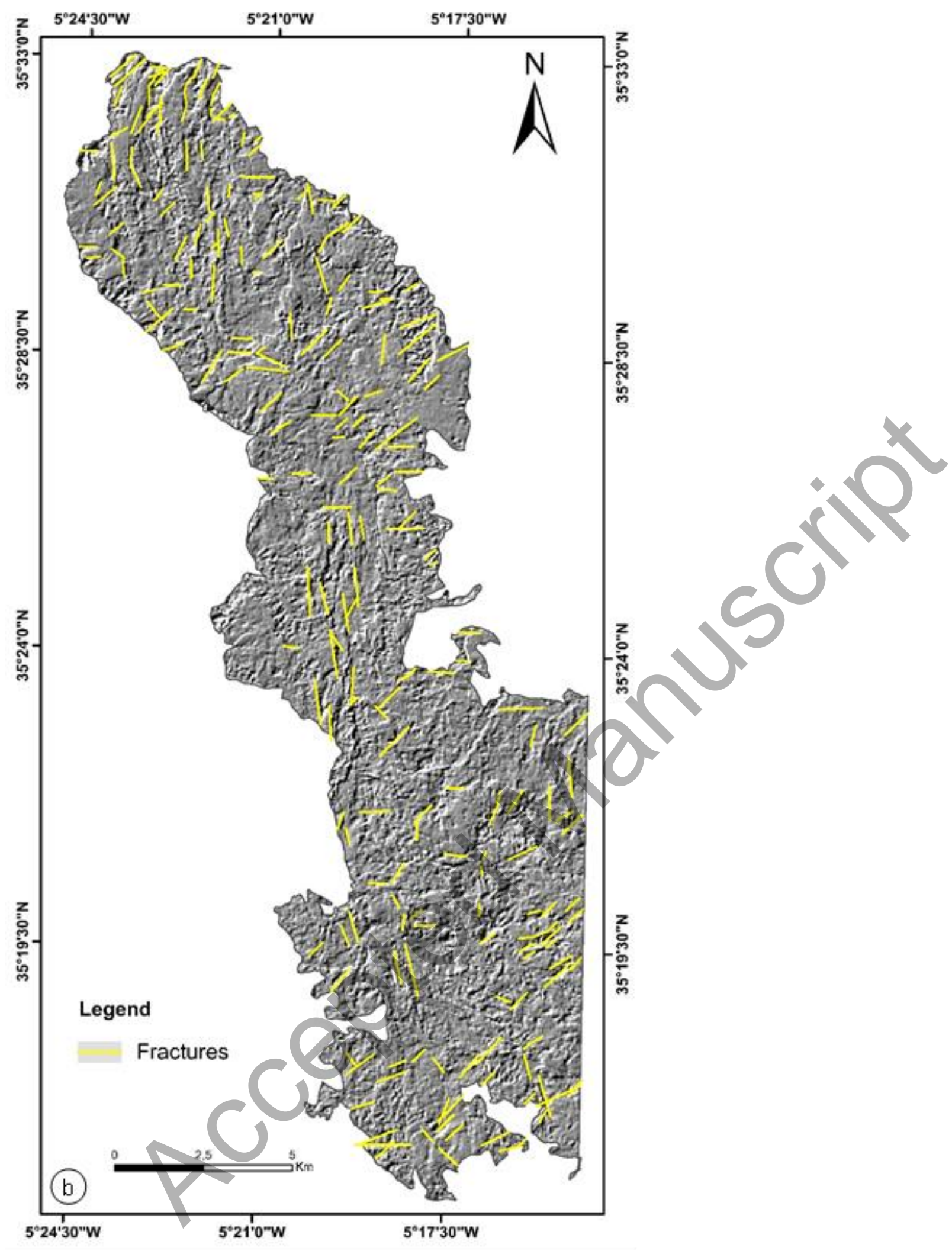




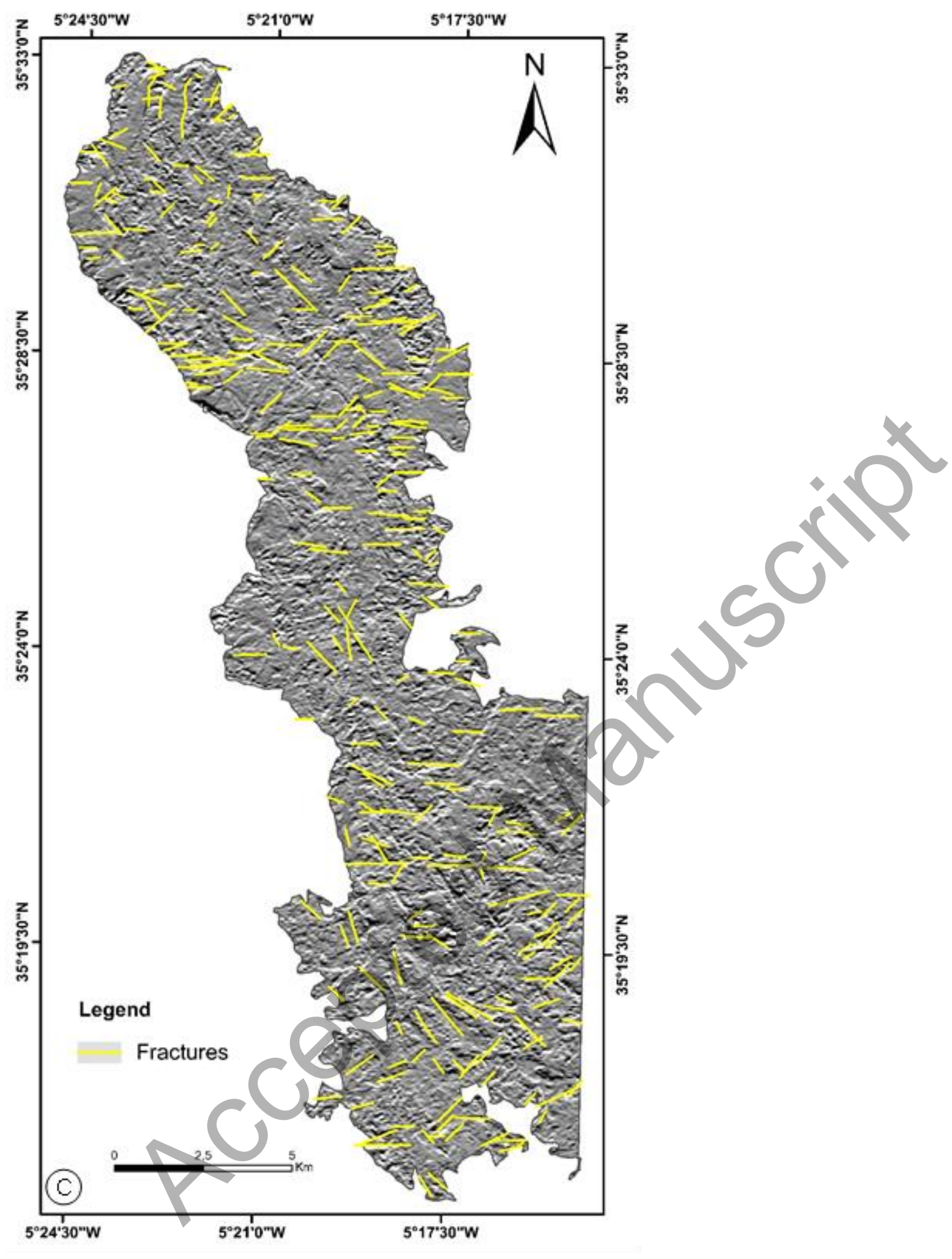




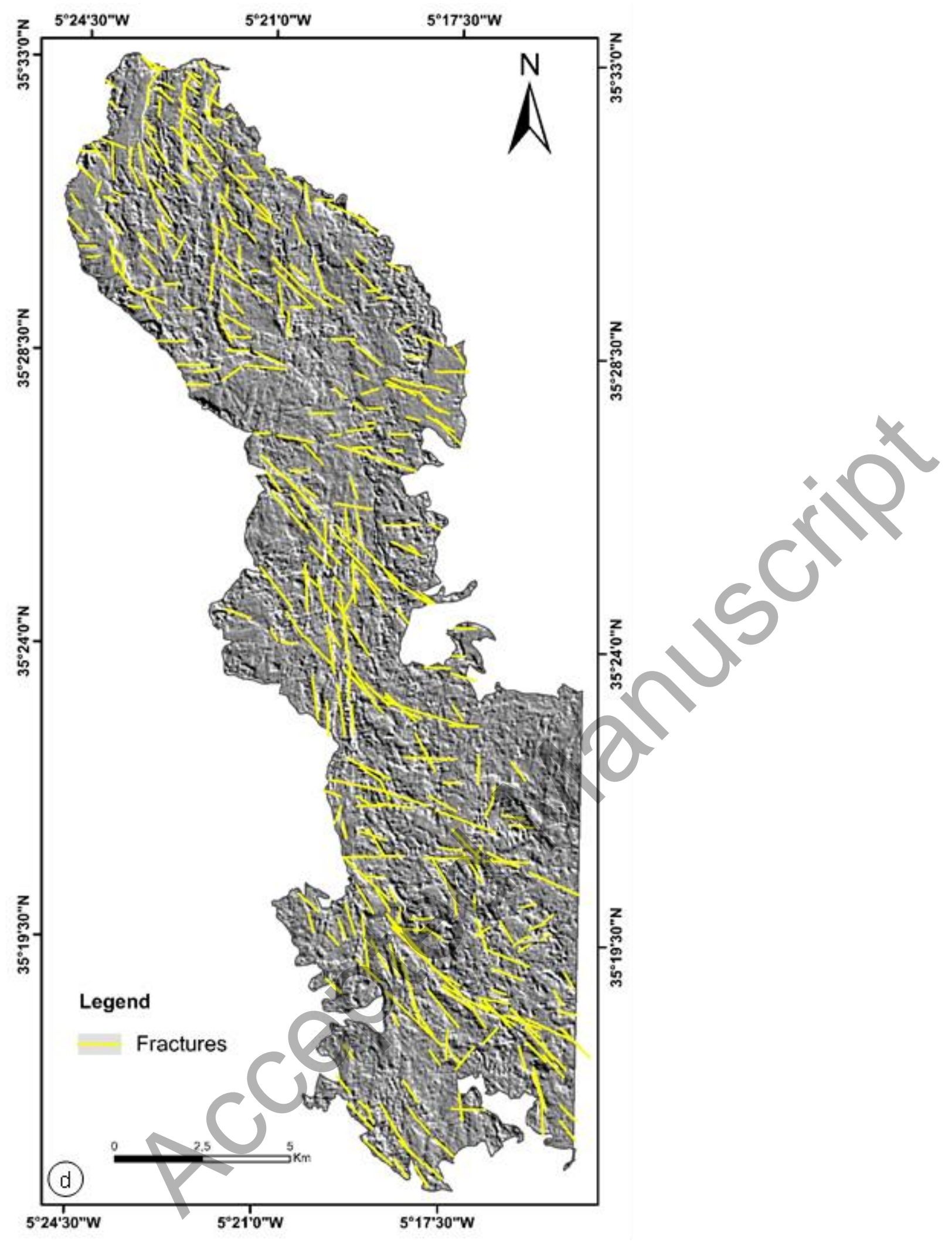

Figure 4. Extracted lineaments in the PC1 image derived from four principal directional filtering for the study area. (a) N-S, (b) NE-SW, (c) E-W and (d) NW-SE. 




Figure 5. Optimum index factor (OIF) RGB color composite image of Band 5 (Red), Band 4 (Green) and Band 1 (Blue) showing lithological units in the study area. 


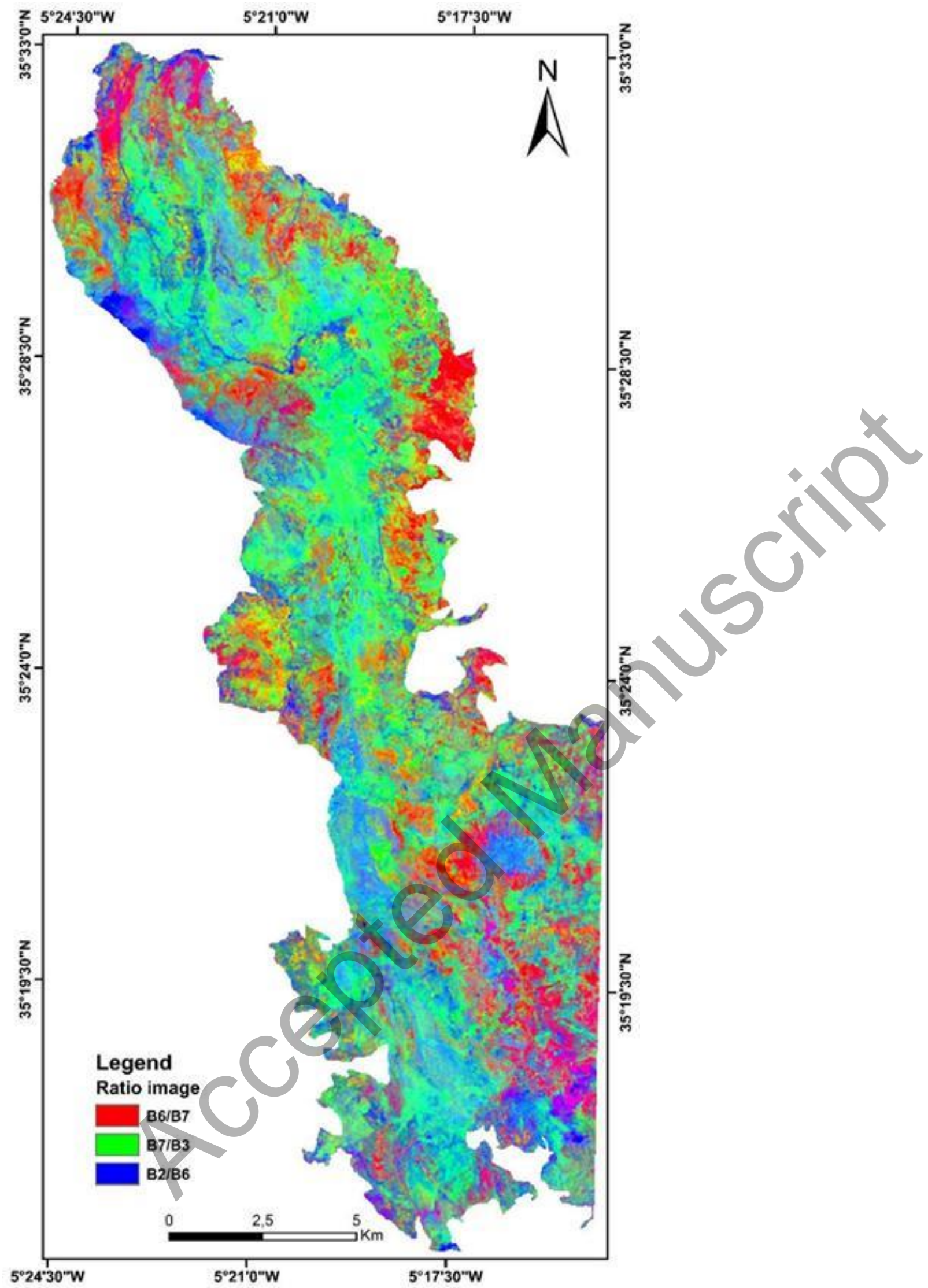

Figure 6. RGB color composite image derived from band ratio of Band6/Band7 (Red), Band7/Band3 (Green) and Band2/Band6 (Blue) showing alteration zones in the study area. 


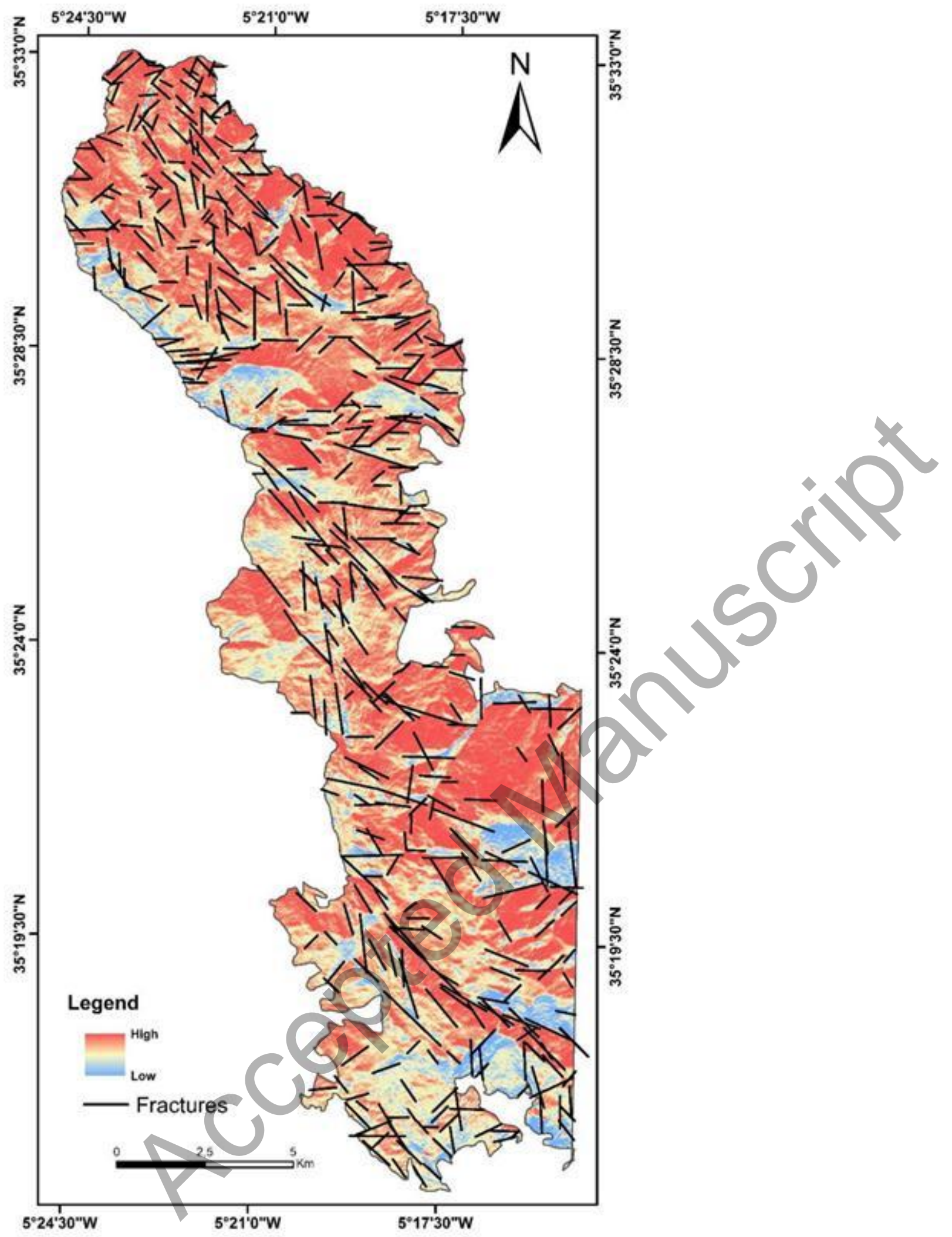

Figure 7. Extracted lineaments on the shaded relief of the study area. It shows spatial distribution of lineaments in the DEM background. 


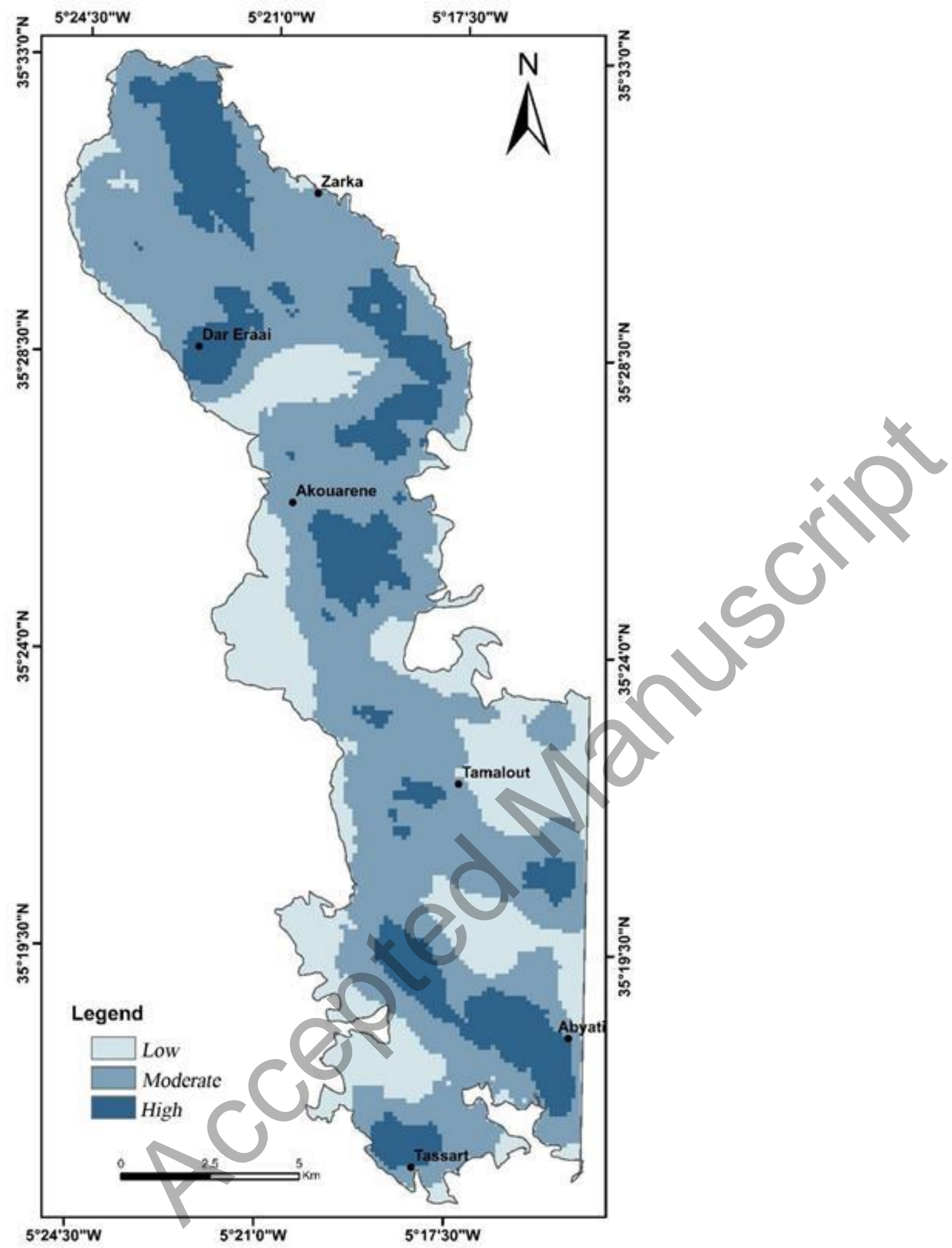

Figure 8. Lineaments density map of the study area. 




Figure 9. (a) Superposition of the extracted lineaments on the pre-existing faults in the geological maps of the study area. (b). Corresponding Rose diagram of the faults digitized from the geological maps. 


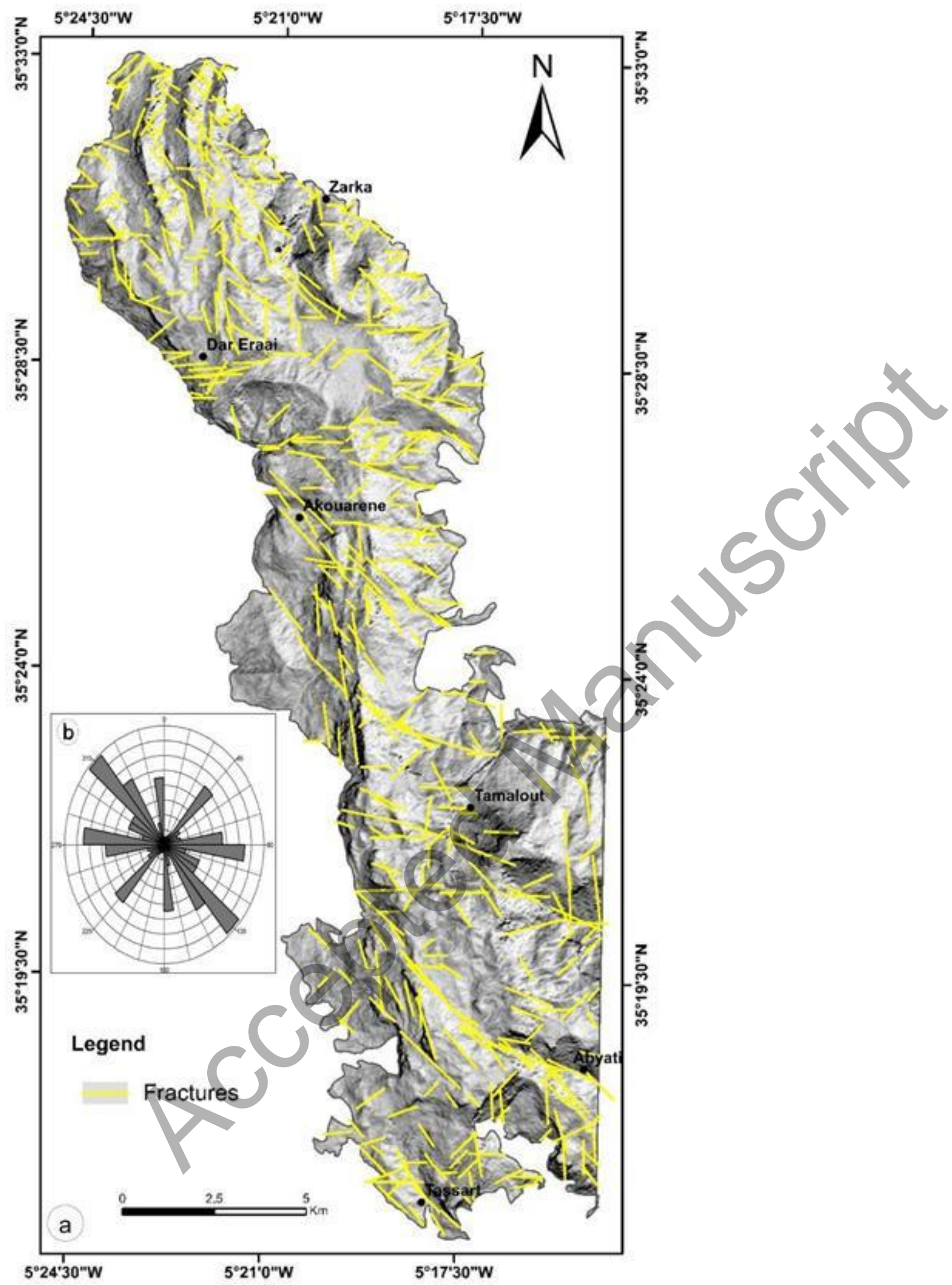




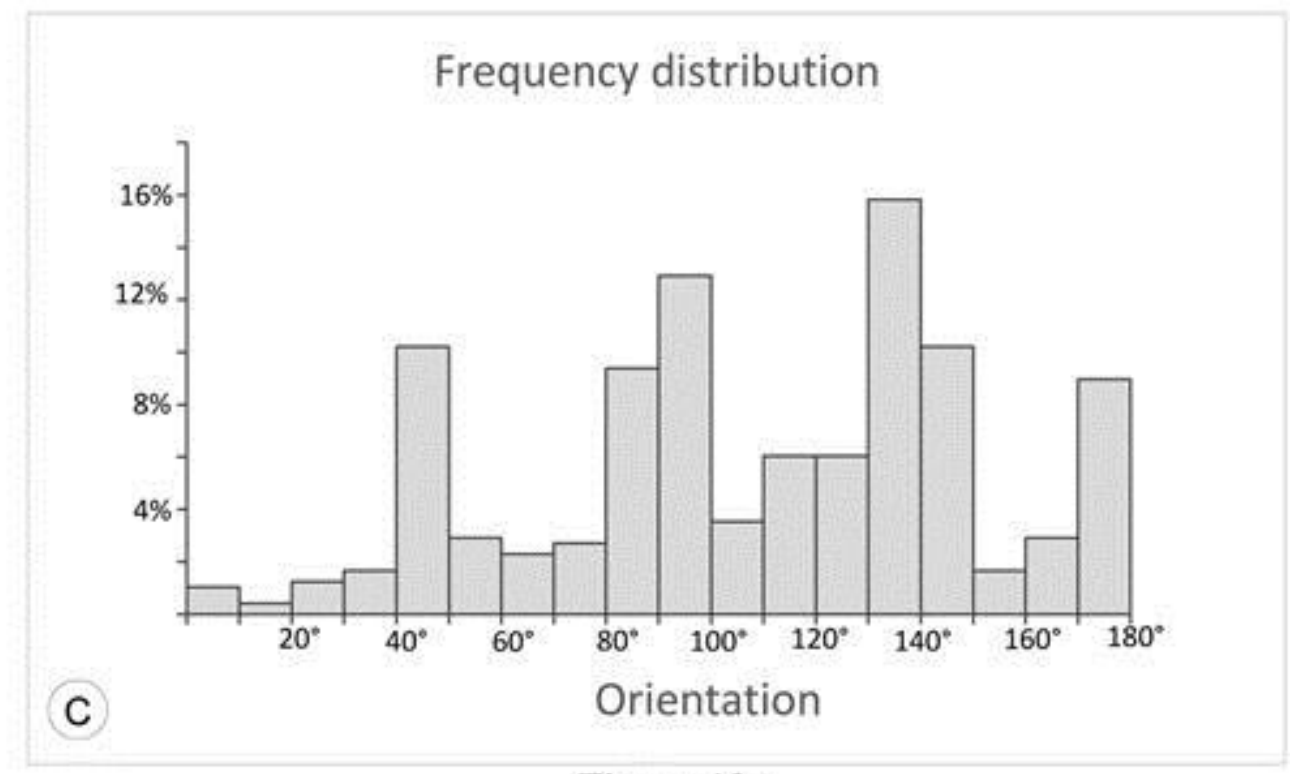

Figure $10 \mathrm{c}$.

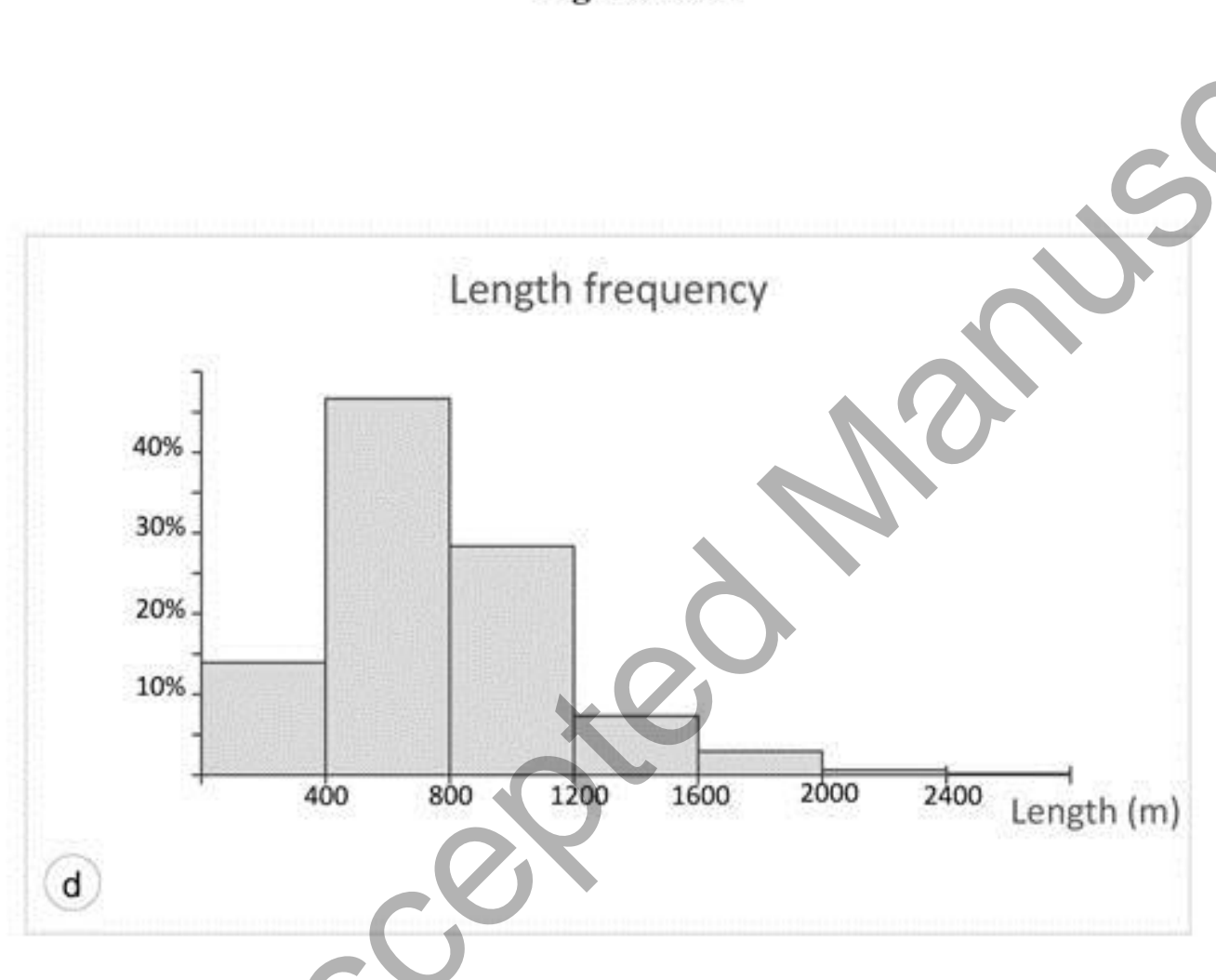

Figure 10 d.

Figure 10. (a) Lineament map of the study area. (b) Rose diagram of the extracted lineaments. (c) Corresponding trend distribution of lineaments. (d) Length frequency diagram of lineaments. 




Figure 11. Field photographs of lineaments and geological structures visited and verified during fieldwork. P1: The Zarka fault; P2: Dar Zkiyek fault; P3: Jbel Bourja fault; P4: The E Dar Eraai sinistral strike-slip fault; P5: The Akouarene fault; P6: Tellouja fault; P7: The Koudiet Aglaguel reverse fault; P8: The Jamaa El Karn sinistral strike-slip fault; P9: The El Ouadiyine fault; P10: The Tassart fault; P11: The Baya reverse fault; P12: The Abyati fault; P13: The Tamalout strike-slip fault. 
Table 1. Technical characteristics of Landsat8 (OLI) (Irons et al., 2012).

\begin{tabular}{|l|c|c|}
\hline OLI spectral band & $\begin{array}{c}\text { Spectral range } \\
(\boldsymbol{\mu m})\end{array}$ & $\begin{array}{c}\text { Spatial resolution } \\
(\mathbf{m})\end{array}$ \\
\hline Band 1: Coastal aerosol & $0.43-0.45$ & 30 \\
\hline Band 2: Blue & $0.45-0.51$ & 30 \\
\hline Band 3: Green & $0.53-0.59$ & 30 \\
\hline Band 4: Red & $0.64-0.67$ & 30 \\
\hline Band 5: Near Infrared & $0.85-0.88$ & 30 \\
\hline Band 6: SWIR 1 & $1.57-1.65$ & 30 \\
\hline Band 7: SWIR 2 & $2.11-2.29$ & 30 \\
\hline Band 8: Panchromatic & $0.50-0.68$ & 15 \\
\hline Band 9: Cirrus & $1.36-1.38$ & 30 \\
\hline
\end{tabular}


Table 2. PCA eigenvectors matrix for Landsat 8 OLI images.

\begin{tabular}{|l|c|c|c|c|c|c|c|c|}
\hline & Band 1 & Band 2 & Band 3 & Band 4 & Band 5 & Band 6 & Band 7 & $\begin{array}{c}\text { Percent of } \\
\text { Eigenvalues }\end{array}$ \\
\hline PC1 & 0.14 & -0.16 & 0.43 & 0.50 & 0.19 & -0.28 & 0.62 & 82.70 \\
\hline PC2 & 0.17 & -0.17 & 0.40 & 0.31 & 0.21 & -0.15 & -0.77 & 12.69 \\
\hline PC3 & 0.26 & -0.13 & 0.39 & -0.06 & -0.07 & 0.86 & 0.08 & 3.57 \\
\hline PC4 & 0.40 & -0.22 & 0.31 & -0.73 & -0.04 & -0.37 & 0.07 & 0.68 \\
\hline PC5 & 0.27 & 0.91 & 0.26 & 0.01 & -0.10 & -0.07 & -0.01 & 0.25 \\
\hline PC6 & 0.62 & 0.03 & -0.49 & 0.03 & 0.59 & 0.09 & 0.04 & 0.07 \\
\hline PC7 & 0.50 & -0.17 & -0.26 & 0.30 & -0.73 & -0.09 & -0.04 & 0.01 \\
\hline
\end{tabular}


Table 3. Correlation matrix between different bands of Landsat 8 OLI.

\begin{tabular}{|l|l|l|l|l|l|l|l|}
\hline & Band 1 & Band 2 & Band 3 & Band 4 & Band 5 & Band 6 & Band 7 \\
\hline Band 1 & 1.00 & 0.98 & 0.92 & 0.88 & 0.24 & 0.73 & 0.80 \\
\hline Band 2 & 0.98 & 1.00 & 0.97 & 0.93 & 0.31 & 0.80 & 0.86 \\
\hline Band 3 & 0.92 & 0.97 & 1.00 & 0.98 & 0.46 & 0.88 & 0.92 \\
\hline Band 4 & 0.88 & 0.93 & 0.98 & 1.00 & 0.43 & 0.91 & 0.94 \\
\hline Band 5 & 0.24 & 0.31 & 0.46 & 0.43 & 1.00 & 0.59 & 0.48 \\
\hline Band 6 & 0.73 & 0.80 & 0.88 & 0.91 & 0.59 & 1.00 & 0.98 \\
\hline Band 7 & 0.80 & 0.86 & 0.92 & 0.94 & 0.48 & 0.98 & 1.00 \\
\hline
\end{tabular}


Table 4. Mean and standard deviation of each band of OLI images.

\begin{tabular}{|c|c|c|c|c|c|c|c|}
\hline & Band 1 & Band 2 & Band 3 & Band 4 & Band 5 & Band 6 & Band 7 \\
\hline $\begin{array}{c}\text { Mean } \\
\text { per } \\
\text { band }\end{array}$ & 103.31 & 104.44 & 106.13 & 111.18 & 181.74 & 151.06 & 132.43 \\
\hline $\begin{array}{c}\text { Std. per } \\
\text { band }\end{array}$ & 57.35 & 60.63 & 65.11 & 68.40 & 41.66 & 55.19 & 61.75 \\
\hline
\end{tabular}


Table 5. OIF score and rank for the band composites in study area.

\begin{tabular}{|l|l|l|l|l|}
\hline Rank & \multicolumn{3}{|c|}{ Composite } & OIF score \\
\hline $\mathbf{1}$ & Band 1 & Band 4 & Band 5 & 108.21 \\
\hline $\mathbf{2}$ & Band 1 & Band 5 & Band 7 & 105.35 \\
\hline $\mathbf{3}$ & Band 1 & Band 2 & Band 5 & 103.91 \\
\hline $\mathbf{4}$ & Band 2 & Band 4 & Band 5 & 102.28 \\
\hline $\mathbf{5}$ & Band 1 & Band 3 & Band 5 & 101.03 \\
\hline $\mathbf{6}$ & Band 2 & Band 5 & Band 7 & 99.44 \\
\hline
\end{tabular}


Table 6. Directional filters with $7 * 7$ kernel matrix.

\begin{tabular}{|c|c|c|c|c|c|c|}
\hline $\mathbf{N}-\mathrm{S}$ & & & & & & \\
\hline-1.0000 & -1.0000 & -1.0000 & 0.0000 & 1.0000 & 1.0000 & 1.0000 \\
\hline-1.0000 & -1.0000 & -1.0000 & 0.0000 & 1.0000 & 1.0000 & 1.0000 \\
\hline-1.0000 & -1.0000 & -1.0000 & 0.0000 & 1.0000 & 1.0000 & 1.0000 \\
\hline-1.0000 & -1.0000 & -1.0000 & 0.0000 & 1.0000 & 1.0000 & 1.0000 \\
\hline-1.0000 & -1.0000 & -1.0000 & 0.0000 & 1.0000 & 1.0000 & 1.0000 \\
\hline-1.0000 & -1.0000 & -1.0000 & 0.0000 & 1.0000 & 1.0000 & 1.0000 \\
\hline-1.0000 & -1.0000 & -1.0000 & 0.0000 & 1.0000 & 1.0000 & 1.0000 \\
\hline \multicolumn{7}{|l|}{ E-W } \\
\hline-1.0000 & -1.0000 & -1.0000 & -1.0000 & -1.0000 & -1.0000 & -1.0000 \\
\hline-1.0000 & -1.0000 & -1.0000 & -1.0000 & -1.0000 & -1.0000 & -1.0000 \\
\hline-1.0000 & -1.0000 & -1.0000 & -1.0000 & -1.0000 & -1.0000 & -1.0000 \\
\hline 0.0000 & 0.0000 & 0.0000 & -0.0000 & -0.0000 & -0.0000 & -0.0000 \\
\hline 1.0000 & 1.0000 & 1.0000 & 1.0000 & 1.0000 & 1.0000 & 1.0000 \\
\hline 1.0000 & 1.0000 & 1.0000 & 1.0000 & 1.0000 & 1.0000 & 1.0000 \\
\hline 1.0000 & 1.0000 & 1.0000 & 1.0000 & 1.0000 & 1.0000 & 1.0000 \\
\hline \multicolumn{7}{|c|}{ NE-SW } \\
\hline-1.4142 & -1.4142 & -1.4142 & -0.7071 & 0.0000 & 0.0000 & 0.0000 \\
\hline-1.4142 & -1.4142 & -1.4142 & -0.7071 & 0.0000 & 0.0000 & 0.0000 \\
\hline-1.4142 & -1.4142 & -1.4142 & -0.7071 & 0.0000 & 0.0000 & 0.0000 \\
\hline-0.7071 & -0.7071 & -0.7071 & 0.0000 & 0.7071 & 0.7071 & 0.7071 \\
\hline 0.0000 & 0.0000 & 0.0000 & 0.7071 & 1.4142 & 1.4142 & 1.4142 \\
\hline 0.0000 & 0.0000 & 0.0000 & 0.7071 & 1.4142 & 1.4142 & 1.4142 \\
\hline 0.0000 & 0.0000 & 0.0000 & 0.7071 & 1.4142 & 1.4142 & 1.4142 \\
\hline \multicolumn{7}{|c|}{ NW-SE } \\
\hline 0.0000 & 0.0000 & 0.0000 & -0.7071 & -1.4142 & -1.4142 & -1.4142 \\
\hline 0.0000 & 0.0000 & 0.0000 & -0.7071 & -1.4142 & -1.4142 & -1.4142 \\
\hline 0.0000 & 0.0000 & 0.0000 & -0.7071 & -1.4142 & -1.4142 & -1.4142 \\
\hline 0.7071 & 0.7071 & 0.7071 & 0.0000 & -0.7071 & -0.7071 & -0.7071 \\
\hline 1.4142 & 1.4142 & 1.4142 & 0.7071 & 0.0000 & 0.0000 & 0.0000 \\
\hline 1.4142 & 1.4142 & 1.4142 & 0.7071 & 0.0000 & 0.0000 & 0.0000 \\
\hline 1.4142 & 1.4142 & 1.4142 & 0.7071 & 0.0000 & 0.0000 & 0.0000 \\
\hline
\end{tabular}

